\title{
Marxist Perspectives on South Korea in the Global Economy
}

Edited by

Martin Hart-Landsberg,

Seongjin Jeong and

Richard Westra 
MARXIST PERSPECTIVES ON SOUTH KOREA IN THE GLOBAL ECONOMY 


\title{
Alternative Voices in Contemporary Economics
}

\author{
Series Editor: \\ Professor Steven Pressman, Monmouth University, USA
}

The Alternative Voices in Contemporary Economics series provides an important platform for new and innovative approaches to economic analysis within the following traditions: Post-Keynesian, Feminist, Institutional, Marxian, Sraffian, Radical, Austrian, and Behavioural. This series offers researchers working in these heterodox traditions the opportunity to address methodological, theoretical or empirical issues. The series editor works closely with authors and editors to ensure the quality of all published works.

Other titles in the Series

\section{Understanding the Entrepeneur An Institutional Perspective \\ Christos Kalantaridis ISBN 978-0-7546-3344-0}

The Economics of Prevailing Wage Laws

Edited by Hamid Azari-Rad, Peter Phillips and Mark J. Prus ISBN 978-0-7546-3255-9

The Ethics and Economics of the Basic Income Guarantee Edited by Karl Widerquist, Michael Anthony Lewis and Steven Pressman ISBN 978-0-7546-4188-9

The Future of the Welfare State European and Global Perspectives

Edited by Bent Greve ISBN 978-0-7546-4640-2

Gandhian Political Economy Principles, Practice and Policy

B.N. Ghosh

ISBN 978-0-7546-4681-5 


\section{Marxist Perspectives on South Korea in the Global Economy}

Edited by

MARTIN HART-LANDSBERG

Lewis and Clark College, USA

SEONGJIN JEONG

Gyeongsang National University, South Korea

RICHARD WESTRA

Pukyong National University, South Korea

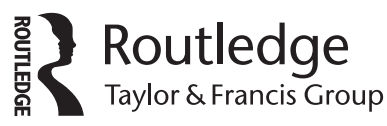

LONDON AND NEW YORK 
First published 2007 by Ashgate Publishing

Published 2016 by Routledge

2 Park Square, Milton Park, Abingdon, Oxon OX14 4RN

711 Third Avenue, New York, NY 10017, USA

Routledge is an imprint of the Taylor \& Francis Group, an informa business

Copyright (C) 2007 Martin Hart-Landsberg, Seongjin Jeong and Richard Westra

Martin Hart-Landsberg, Seongjin Jeong and Richard Westra have asserted their right under the Copyright, Designs and Patents Act, 1988, to be identified as the editors of this work.

All rights reserved. No part of this book may be reprinted or reproduced or utilised in any form or by any electronic, mechanical, or other means, now known or hereafter invented, including photocopying and recording, or in any information storage or retrieval system, without permission in writing from the publishers.

Notice:

Product or corporate names may be trademarks or registered trademarks, and are used only for identification and explanation without intent to infringe.

\section{British Library Cataloguing in Publication Data}

Marxist perspectives on South Korea in the global economy.

- (Alternative voices in contemporary economics)

1. Marxian economics 2. Korea (South) - Economic conditions

- 1960- 3. Korea (South) - Economic policy - 1960- 4. Korea

(South) Foreign economic relations

I. Hart-Landsberg, Martin II. Jeong, Seongjin III. Westra,

Richard, 1954-

$330.9 ' 5195$

\section{Library of Congress Cataloging-in-Publication Data}

Marxist perspectives on South Korea in the global economy / edited by Martin Hart-Landsberg, Seongjin Jeong and Richard Westra.

p. cm. -- (Alternative voices in contemporary economics)

Includes bibliographical references and index.

ISBN-13: 978-0-7546-4816-1 1. Korea (South)--Economic

conditions--1960- 2. Korea (South)--Economic policy--1960- I. Hart-Landsberg, Martin. II. Jeong, Seongiin. III. Westra, Richard, 1954-

HC467.95.M37 2007

$330.95195--\mathrm{dc} 22$

2006031594

ISBN 9780754648161 (hbk)

ISBN 9781138228115 (pbk) 


\section{Contents}

List of Figures vii

List of Tables ix

List of Contributors xi

Preface and Acknowledgements xv

Introduction: Marxist Perspectives on South Korea in the Global Economy

Martin Hart-Landsberg, Seongjin Jeong and Richard Westra

\section{Part I Marxian Method and South Korean Capitalism}

Introduction to Part I

1 Trend of Marxian Ratios in Korea: 1970-2003

Seongjin Jeong

2 Uneven Development of the Rates of Surplus Value:

The Case of South Korea

Dong-Min Rieu

3 State, Market, and Stages of Capitalism in South Korean

Development

Richard Westra

\section{Part II The South Korean Economy in Global Perspective}

Introduction to Part II

4 China and the Dynamics of Transnational Capital Accumulation Martin Hart-Landsberg and Paul Burkett

5 The Changing Patterns of Accumulation and Realization in East Asia since the 1990s

Joseph Halevi and Peter Kriesler 


\section{Part III The South Korean Economy in Historical Perspective}

Introduction to Part III

6 Land Reform and Capitalist Development in Korea Sang-Hwan Jang

7 A Critical Reappraisal of the Park Chung Hee System Soohaeng Kim and Seung-Ho Park

\section{Part IV The South Korean Economy into the Future}

Introduction to Part IV

8 The South Korean Economy: Problems and Prospects Martin Hart-Landsberg

9 When Capital Becomes Society: The Re-composition of Capitalist Work and New Labor Activism in Korea Dae-oup Chang

Appendix: Major Political and Economic Events in Korea, 1945-2006 


\section{List of Figures}

Figure 1.1 Classification of Productive and Unproductive Workers using Occupation Categories

Figure 1.2 Classification of Productive and Unproductive Workers using Job Class Categories $\quad 37$

Figure 1.3 Ratio of Productive Workers (Lp/L) by Industry, 1980-2003 40

Figure 1.4 Ratio of Productive Wages (Wp/W) by Industry, 1980-2003 40

Figure 1.5 Ratio of Productive Workers (Lp/L) in Manufacturing Sector by Data Source, 1970-2003

Figure 1.6 Ratio of Productive Wages $(\mathrm{Wp} / \mathrm{W})$ in Manufacturing Sector by Data Source, 1970-2003

Figure 1.7 Ratio of Average Wage of Productive/Unproductive Workers (wp/wu) in Manufacturing Sector, 1980-2003

Figure 1.8 Ratio of Productive Workers and Wages of all Industries in Korea, 1980-2003

Figure 1.9 Composition of Productive/Unproductive Workers of all Industries in Korea, 1980-2003

Figure 1.10 Composition of Productive/Unproductive of all Industries in Korea, 1980-2003

Figure 1.11 Estimation of Marxian Categories using Input-Output Tables (Shaikh and Tonak, 1994)

Figure 1.12 Estimation of Marxian Categories using Input-Output Tables (Wolff, 1987)

Figure 1.13 Estimation of Marxian Categories using Input-Output Tables (Mage, Mohun, Moseley)

Figure 1.14 Rate of Surplus Value in Korea in all Industries in Korea, 1980-2000

Figure 1.15 Estimates of Rate of Surplus Value in Korea Using Various Methods, 1980-2000

Figure 1.16 Comparison of Estimates of Rate of Surplus Value in Korea, 1985-2000

Figure 1.17 Distribution of Surplus Value in Korea, 1980-2000

Figure 1.18 Constant Capital, Variable Capital and Surplus Value in Korea, 1980-2000

Figure 1.19 Composition of Total Value $(c+v+s)$ in Korea, 1980-2000

Figure 1.20 Comparison of GDP with Marxian Value Added $(v+s)$ in Korea, 1980-2000

Figure 1.21 Rate of Profit in Non Farm Business Sector in Korea, 1970-2000 
Figure 1.22 Rate of Profit in Korea, 1970-2000

Figure 1.23 Rate of Profit in Korea, without Correcting for Wage Equivalent of Self-Employed, 1970-2002

Figure 1.24 Determinants of Rate of Profit in Non Farm Business Sector, 1970-2002

Figure 1.25 Trend of Determinants of Rate of Profit in Non Farm Business Sector, 1970-2002

Figure 1.26 Trend of Determinants of Output-Capital Ratio in Non Farm Business Sector, 1970-2002

Figure 1.27 GDP Deflator (Py) and Net Capital Stock Deflator (Pk) in Non Farm Business Sector, 1970-2002

Figure 1.28 Trend of Determinants of Profit Share in Non Farm Business Sector, 1970-2002

Figure 1.29 Industrial Rates of Profit in Korea, 1970-2002

Figure 1.30 Rate of Profit in Manufacturing and Financial Sector in Korea, 1970-2002

Figure 2.1 Inter-temporal Ratio of Sectoral Rates of Surplus Value

a) Year 1995/Year 1990

b) Year 2000/Year 1995

c) Year 2000/Year 1990

Figure 2.2 Sectoral Rates of Surplus Value 78

Figure 3.1 Levels of Analysis in Marxian Political Economy 89

$\begin{array}{llr}\text { Figure } 3.2 & \text { Stages of Capitalism } & 92\end{array}$

Figure 3.3 The Stage of Consumerism and Korean Capitalism 104

Figure 3.4 Globalization/Neo-liberalism as a Period of Transition 106 


\section{List of Tables}

Table 1.1 Classification of Productive and Unproductive Sectors in Korea 36

Table 1.2 Decomposition of the Trend of Rate of Profit in Korea, 1970-2002

Table 1.3 Decomposition of the Trend of Profit Share and Output-Capital Ratio, 1970-2002

Table 2.1 Sectoral Quantity of Embodied Labor (hour/million Won) 75

Table 2.2 Sectoral Rates of Income (Won/hour) 76

Table 2.3 Inter-temporal Ratios of the Sectoral Rates of Surplus Value $\quad 78$

Table 2.4 Inter-temporal Value Ratios $\quad 79$

Table 2.5 Sectoral Rates of Surplus Value $\quad 80$

Table 2A.1 Classification of Industry (KSIC) 81

Table 4.1 Net Foreign Direct Investment in China, billions US\$ 116

Table 4.2 Net Foreign Direct Investment in East Asia, billions US\$ 117

Table 4.3 Direction of Exports of Manufactures, percent of National Total 119

$\begin{array}{lll}\text { Table 4.4 Export Shares in US Market, in percent } & 120\end{array}$

Table 4.5 Composition of East Asian Manufactured Exports, in percent 121

Table 4.6 China's Net Trade with East Asia, billions US\$ 122

Table 4.7 Parts and Components, Shares of Manufactured Exports $\begin{array}{ll}\text { and Imports } & 124\end{array}$

Table 4.8 Parts and Components Share of Trade in Selected Markets 125

Table 6.1 Land Area and Farm Households under Tenancy 161

Table 6.2 Proposals of Various Land Reform Bill 167

Table 6.3 Object Area of Distribution: Korean-owned Land (June 21, 1949) 169

Table 6.4 Total Area of Distributed Land 170

Table 6.5 Change of Tenanted Area before and after Land Reform 171

Table 6.6 Farm Households by Farm Size under Cultivation (\%) 174

Table 6.7 Settlement of Special Accounts for Land Reform Project 175

Table 6.8 Increase of Students in High School and Above (1945-1960) 177

Table 6.9 Increase of Students in Elementary and Middle School 177

Table 6.10 Ratio of Urban Population and the Non-farm Employed (1950-1990, \%)

Table 6.11 Rural-to-urban Migrants (1965-1990) 179

Table 6.12 Education Level of Rural-to-urban Migrants (1965-90, \%) 179

Table 8.1 South Korean Growth, in percent 204

Table 8.2 Foreign Direct Investment into South Korea, billions US\$ 205

Table 8.3 South Korea's Trade Orientation, in percent 208 
$\fallingdotseq$ Taylor \& Francis

Taylor \& Francis Group

http://taylorandfrancis.com 


\section{List of Contributors}

Paul Burkett is Professor of economics at Indiana State University, Terre Haute, USA. His research focuses on the political economy of development and class struggle, and Marxism and ecology. He is the co-author, with Martin HartLandsberg, of China and Socialism: Market Reforms and Class Struggle (Monthly Review Press, 2005) and the author of Marxism and Ecological Economics: Toward a Red and Green Political Economy (Brill, 2006).

Dae-oup Chang is an academic activist working for the Asia Monitor Resource Centre in Hong Kong as the research coordinator. He is also the coordinator of Asian Transnational Corporation Monitoring Network, which consists of 20 labor NGOs and unions, and which is involved in developing theories and practices of organizing labor against mobile capital in Asia. He earned his Ph.D from the Department of Sociology at University of Warwick. His works on the transformation of the social form of labor in Korea and other Asian developing countries under the impact of globalization have been published in Journal of Contemporary Asia, Labour, Capital and Society, Historical Materialism, and Asian Labour Update. He is currently working on a number of research projects analyzing the way in which the social form of labor has been recomposed by the transnational corporate-driven globalization and a new labor activism emerging from the struggle against the new social domination of capital in Asia.

Joseph Halevi is Senior Lecturer for the Discipline of Political Economy, School of Economics and Political Science, University of Sydney, Australia. Halevi was born in Israel and studied and lived in Rome. He has previously taught at the New School for Social Research in New York, and at the University of Connecticut. He is periodically invited by the Universities of Grenoble, and of Nice, both in France. He has contributed several articles to the journal Monthly Review and co-edited two books: Restoring Demand in the World Economy, with Jean Marc Fontaine (Edward Elgar, 1998), and, with David Laibman and Edward Nell, Beyond the Steady State (St Martins' Press/ Macmillan, 1992). He is currently researching on the political economy of Europe and of East Asia in relation to the United States.

Sang-Hwan Jang is Professor of Economics at Gyeongsang National University, Korea where he teaches agricultural economics and Korean economy. He received his $\mathrm{PhD}$ from Yonsei University, Seoul and served as Chairman of the Policy Committee for the Democratic Labor Party of Korea from 2000 to 2003. Since 2004, he has worked as Director of the Progressive Politics Institute for this party. He spent a one year sabbatical at the Department of Economics, University of Massachusetts, 
Amherst, 2003-2004. His MA thesis, "An Empirical Study on Land Reform in Korea (1985, in Korean)" was evaluated as a thoroughgoing field study, criticizing the previous estimates of the reform. He has written many articles (in Korean) on problems of the agricultural economy, farmland policy, and economic policy of Korea. His recent publications include, "Continuing Suicide among Laborers in Korea", Labor History (2004). Currently he is conducting research on alternative economic policy for developing countries in opposition to neo-liberalism.

Seongjin Jeong is Professor of economics and former Director of the Institute for Social Sciences at Gyeongsang National University, South Korea. He received his $\mathrm{PhD}$ from Seoul National University, and has written widely on Marxism and the Korean economy, including articles in Review of Radical Political Economics and Rethinking Marxism. He has also translated some major Marxist works into Korean, including books by Robert Brenner, Alex Callinicos, Tony Cliff and Roman Rosdolsky. He is currently editing MARXISM 21, a representative Marxist journal in Korea.

Soohaeng Kim is Professor of economics at Seoul National University, South Korea and is Honorary President of Korea Social and Economic Studies Association (KSESA), a Korean Left Economists' Group, and President of Cyber Labor University in memory of Chun Taeil. Kim is a graduate of Seoul National University, BA and MA, and Birkbeck College, University of London, MSc and PhD. He wrote a doctoral thesis on Marx's theory of crisis. His main intellectual contribution to Marxism is his translation into Korean of the complete three volumes of Marx's Capital.

Peter Kriesler is Associate Professor in the School of Economics at the University of New South Wales, Australia. He is also Deputy Director, there, for the Centre for Applied Economic Research, executive editor of the Australian Journal of Human Rights, and on the editorial board of the Economic and Labour Relations Review, and History of Economics Review. He is the organizer of the Annual Australian Society of Heterodox Economists Conference, which is now in its fifth year. His work has been published in numerous scholarly journals including Cambridge Journal of Economics, the Journal of Post Keynesian Economics, the Review of Political Economy and Economies et Societes. He is author of Kalecki's Microanalysis: The Development of Kalecki's Analysis of Prices and Distribution (Cambridge, 1987), revised and translated into Japanese (2000); editor of The Australian Economy: The Essential Guide (Allen \& Unwin 1999); Globalisation, Human Rights and Civil Society (Prospect Media Ltd., 1998); and Themes in Political Economy: Essays in Honour of Geoff Harcourt (Routledge, 1999). His current research relates to the Australian, Asian and European economies, Marxian and Kaleckian economics, and issues related to employment and path determinacy. 
Martin Hart-Landsberg is Professor of economics at Lewis and Clark College, Portland, Oregon, USA and directs the political economy program there. His areas of teaching and research include the political economy of development with an emphasis on East Asia. He is the co-author, with Paul Burkett, of China and Socialism: Market Reforms and Class Struggle (Monthly Review Press, 2005) and Development, Crisis, and Class Struggle: Learning from Japan and East Asia (St. Martin's Press, 2000).

Seung-Ho Park is Research Professor of the Institute for Social Sciences at Gyeongsang National University, South Korea. He graduated from Seoul National University with BA and MA degrees. Having contributed to working class movements for more than ten years, he returned to Seoul National University and obtained his PhD Degree with a thesis on Marxian Critique of Left Theories of Modern Capitalism. He is one of the founding members of Cyber Labor University in memory of Chun Taeil.

Dong-Min Rieu is Associate Professor of economics at Chungnam National University, South Korea. He received his $\mathrm{PhD}$ from Seoul National University. He has written mainly on Marxian value theory in academic journals including: Kobe University Economic Review, Review of Radical Political Economics and Seoul Journal of Economics.

Richard Westra has taught at universities and colleges around the world including: The Royal Military College of Canada, Queen's University, Kingston, Ontario, the International Study Centre, East Sussex, UK and the College of the Bahamas, Nassau. Currently, he is Assistant Professor in the Division of International and Area Studies, Pukyong National University, Pusan, South Korea. His work has been published in numerous international scholarly refereed journals including: Journal of Contemporary Asia, Capital and Class, Review of International Political Economy and Review of Radical Political Economics. He has also co-edited and contributed to the volumes: Phases of Capitalist Development: Booms, Crises and Globalizations (Palgrave, 2001) which has recently been translated into Chinese and published by Economic Science Press, Beijing (2003); Value and the World Economy Today: Production, Finance and Globalization (Palgrave, 2003); New Socialisms: Futures beyond Globalization (Routledge, 2004); and Sustaining Life On Earth: Environmental and Human Health Through Global Governance (Lexington Books, 2006). 
$\fallingdotseq$ Taylor \& Francis

Taylor \& Francis Group

http://taylorandfrancis.com 


\section{Preface and Acknowledgements}

This volume is the result of our shared concern with developments in South Korea (hereafter Korea) and belief in the continued relevance and power of Marxism to provide critical insight into contemporary Korean struggles and choices. While the focus of Marxist Perspectives on South Korea in the Global Economy is the Korean experience, we also believe that the broader significance of that experience as well as the nature of our approach will make our work relevant to those concerned with development and social change more broadly.

In the heady days of neoliberalism, marked by United States President Ronald Reagan's denunciation of the Soviet Union as the "Evil Empire" and British Prime Minister Margaret Thatcher's pronouncement that "there is no alternative" to neoliberal globalization, advocates of Marxism as a mode of analysis and inspiration for the future found themselves routinely dismissed as irrelevant (if not literally dismissed from their positions). This was especially true within the Western academy, where the Marxist research focus on materialist explanation was sanitized and references to Marxist works were purged from bibliographies. Cowed by the neoliberal intellectual offensive many Marxist influenced scholars sought refuge in poststructuralist and postmodern analysis where their revolutionary élan could be plied subverting meaning in texts.

In no part of the academy was the abandonment of Marxism more devastating than in development studies and its related fields. Here, the retreat gained momentum from two important world-economic developments: the collapse of Soviet-style socialism and the rise of the so-called East Asian "miracle economies" (with Korea perhaps the most prominent). These developments empowered neoliberals to make the most sweeping assertions about capitalist development and the economic benefits to be derived from a global unbridling of markets.

Eventually, these assertions were challenged, most effectively by a small but increasingly influential group of left-Keynesian/statist social scientists. Drawing their lessons from the East Asian experience, these analysts advocated a new "conventional wisdom," one that celebrated the role of the developmental state rather than the market as the engine of development. The sharpness of the debate between the two positions tended to overshadow the fact that both sides shared a number of critical assumptions, the most important being that capitalism was the only system capable of supporting development. As a consequence, Marxism was pushed even further to the intellectual margins in development studies, economics, and political economy.

However, despite neoliberal and left Keynesian/statist dismissals of the importance of Marxist categories and insights (including those related to class, crisis, and imperialism), Marxist voices were never completely silenced. And, 
as capitalism's own accumulation dynamics led to ever-greater exploitation and instability throughout the world, including East Asia, these voices have become louder. Given the critical role played by Korea as an intellectual battleground for the debate between left Keynesian/statists and neoliberals, it is especially noteworthy that there has been a resurgence of Marxist-informed analyses of the Korean experience and by Korean scholars. There is great need for such work as the recent crisis in Korea and resulting capitalist restructuring have intensified class tensions and presented social movements there with new and difficult challenges.

This was the context for our decision to organize a conference in May 2005 on Marxist perspectives on South Korea with the goal of turning the conference papers into an edited collection. The conference was held at Gyeongsang National University in Jinju, South Korea, under the direction of the Institute for Social Sciences of Gyeongsang National University, as part of their international coresearch project, "Change of Accumulation Regime in Korea: 1987-2003." Among the authors of the volume, Martin Hart-Landsberg, Sang-Hwan Jang, and Seongjin Jeong are also co-researchers with the project.

What makes this volume distinctive is that the majority of papers presented and included in this volume are by Koreans. Unfortunately because of language difficulties work by Korean authors tends to remain largely unknown outside of Korea. Indeed, language difficulties have generally forced progressive scholars in the West to rely solely on Western (or Western influenced) mainstream sources for their insights into the Korean development experience, thereby contributing to a misleading understanding of that experience. We hope that the melding of Western and Korean Marxist scholarship in this volume will provide much deserved visibility to Korean Marxist scholarship and help correct many of the misunderstandings and politically motivated misrepresentations of the Korean experience.

Finally, the editors (as well as all the contributors to the volume) wish to express their gratitude for the many comments and suggestions provided by other conference participants, including Alex Callinicos, Jin-Sang Jeong, Ohnishi Hiroshi, Moohyeon Joo, Nam-Hoon Kang, Eui-Dong Kim, Chai-on Lee, Jong-Lae Lee, and Lefteris Tsoulfidis. Financial support from a Korea Research Foundation Grant (KRF-2003005-B00006) for the project and the conference is also gratefully acknowledged.

Martin Hart-Landsberg (Portland, OR USA) Seongjin Jeong (Jinju, South Korea) Richard Westra (Pusan, South Korea) 


\title{
Marxist Perspectives on South Korea in the Global Economy
}

\author{
Martin Hart-Landsberg, Seongjin Jeong and Richard Westra
}

This edited volume is about South Korea (hereafter Korea). More specifically, it offers a critical examination of Korea's past growth; recent crisis; and contemporary restructuring, struggles, and challenges. Most neoliberal as well as left-Keynesian/ statist economists celebrate Korea as a capitalist success story, although they have different explanations for the country's success. We disagree with this characterization of the Korean experience. In brief, as we argue below, the country's past growth was heavily dependent on historically specific conditions (including a powerful state and a supportive international economic environment), and came at high cost for most Koreans (based as it was on dictatorship and exploitation). Eventually, contradictions generated by this growth, which were intensified by changing international conditions, triggered a crisis that has undermined past industrial achievements and increased competitiveness pressures, leading to deteriorating living and working conditions for the majority of Koreans. In short, we believe that our collective examination of the Korean experience offers important insights into the limits of and contradictions inherent in capitalist growth.

As the title - Marxist Perspectives on South Korea in the Global Economy - makes clear, this volume is also about Marxism. In particular, it is a Marxian perspective that guides our examination of the Korean experience. This perspective differs sharply from both the neoliberal and left Keynesian/statist ones that currently dominate debates about Korea in the fields of economics, development studies, and political economy. By highlighting the relevant differences, this book also seeks to demonstrate the superiority of Marxism as a framework for understanding both the Korean development experience (and by extension capitalist dynamics more generally) and the contemporary challenges facing Koreans as they struggle to build a new, more responsive political-economy.

\section{The Celebration of the Korean Growth Model}

Korea's recent growth record has been impressive. The country's real GDP grew by an average of 9 percent during the 1960s, 9.3 percent during the 1970s, and by nearly 10 percent during the 1980s and the first half of the 1990s. Equally impressive was the country's industrial transformation. By 1996, South Korea ranked as the number one "supplier of computer memory chips, the second largest shipbuilder in the world, the third largest producer of semiconductors, the fourth largest maker of electronics, 
the fifth largest car maker, and the largest steel producer" (Cathie, 1997/1998, 22). On the strength of this performance, Korea went from being a "basket case" in the 1950 s to a member of the Organization for Economic Cooperation and Development (OECD) in 1996.

Several other East Asian countries/economies, in particular Hong Kong, Indonesia, Malaysia, Singapore, Taiwan, and Thailand, have also been celebrated for their recent growth achievements. What makes this record of East Asian gains especially noteworthy is that it stands in sharp contrast to the performance of the rest of the third world. As the IMF explains:

Korea, for example, experienced almost a ten-fold rise in per capita income between 1965 and 1995, while Thailand saw a five-fold increase, and Malaysia a four-fold rise. In the developing countries of the Western Hemisphere average per capita incomes doubled between 1965 and 1980 before stagnating over the next 15 years, a period much of which was dominated by the debt crisis and its aftermath. ... While the [East Asian] success stories illustrate that dramatic improvements in living standards are possible, many countries regrettably are not realizing their potential. In relative terms, most developing countries have failed to raise their per capita incomes toward those of the industrial countries. In fact, Asia is the only major region to have registered significant relative progress, in the sense of having achieved significant convergence towards industrial country living standards (International Monetary Fund, 1997, 76-7).

Even within this group of fast growing East Asian countries, Korea has often been singled out for praise. For example, Alice Amsden (an advocate of the developmental state) has argued that South Korea "can serve as a useful model from which other aspiring industrializing countries can learn" (Amsden, 1989, v-vi). Donald Keesing, writing in a World Bank working paper, concluded that "application in new settings of the combination of what is now known and recommended - particularly in countries well along in the process of development - gives very encouraging results, even if it does not turn other countries into success stories on the same scale as Korea". Similarly, in an examination of the industrialization experience of seven "of the more advanced developing countries" - Hong Kong, Malaysia, Mexico, Korea, Singapore, Taiwan, and Turkey - over the period 1981-1996, the United Nations Conference on Trade and Development (UNCTAD) concluded that "of these countries, the Republic of Korea stands alone, with a production-trade configuration similar to that of the major industrial countries" (UNCTAD, 2002a, 77).

In short, by the late $1980 \mathrm{~s}$, economists across a wide political spectrum were promoting the fast growing East Asian countries, and Korea in particular, as model developers whose experiences should be studied and emulated. While many of these economists did acknowledge that there were costs associated with the East Asian development process - including repression of civil, human, and labor rights, and the destruction of the environment - they generally considered them to be inconsequential compared with the benefits generated by the region's rapid growth.

1 As quoted in Linder $(1986,41)$ 
Moreover, they tended to view them as temporary, unavoidable consequences of the transition out of underdevelopment. Thus, continued economic growth was seen as the best response to whatever problems might exist.

The only area of controversy that marred this almost unanimous endorsement of the East Asian experience was disagreement over the policies that accounted for the region's rapid growth. Neoliberal economists credited market forces, while leftKeynesian/statists credited active state industrial policy.

Neoliberal economists have generally proven quite opportunistic. They have embraced any country's experience if it appears positive, claiming that it demonstrates the superiority of market forces as an engine of development. Sadly, their positions of authority in the top universities, research institutions, and international organizations have given their claims undeserved credibility. Such is the case with the East Asian experience and neoliberal assertions of market led development. For example, in a 1987 study for the Institute for International Economics, Bela Balassa and John Williamson claimed that the East Asian newly industrializing countries (NICs; Korea, Taiwan, Hong Kong, and Singapore) had outperformed the Latin American NICs and India because of their rejection of industrial policy:

More generally, the scope of administrative controls was much more limited in the four East Asian NICs than in Latin America and, even more, India. In the latter case, there were pervasive controls on investment, prices, and imports, and decisions were generally made case by case, thereby creating uncertainty for business and opportunities for corruption, which has remained comparatively limited in East Asia....Capital markets, too, were freer in the East Asian NICs than in Latin America and India (Balassa and Williamson, 1987, 14-15).

Even when neoliberal economists acknowledged the existence of planning, as in the case of Korea, they dismissed its importance. According to Paul Kusnets:

The coincidence of rapid growth and economic planning, and primacy of the Economic Planning Board in the circle of economic ministries have led some observers to misconstrue the function of planning and overemphasize the role of government in the Korean economy. Planning does not entail government control of resource allocation, but rather involves a set of activities designed to sustain rather than repress market functions. The government acts by providing information, reducing risks, and altering incentives rather than by fiat or by assuming market or enterprise functions (Kusnets, 1982, 85).

This view of the role of markets in the East Asian experience, especially in the case of Korea, was clearly wrong, and by the late 1980s a small but influential group of left-Keynesian/statist economists had begun to successfully challenge it. For example, as Alice Amsden noted:

Korea is an example of a country that grew very fast and yet violated the canons of conventional economic wisdom. ... In Korea, instead of the market mechanism allocating resources and guiding private entrepreneurship, the government made most of the pivotal investment decisions. Instead of firms operating in a competitive market structure, they 
each operated with an extraordinary degree of market control, protected from foreign competition (Amsden, 1989, 139).

Byong-Nak Song, an economist with experience at government planning agencies and research institutes in Korea, offered a similar perspective on the critical role of the state in Korean development:

Under the government export promotion strategy, "survival of the fittest" among competing firms was not determined in the marketplace, but through discretionary government actions. "Fitness" was judged in terms of the ability to expand exports, rather than based on profitability. If determined "unfit," firms were likely to face bankruptcy. Such firms were under constant threat of tax investigations and other punitive sanctions. On the other hand, firms that efficiently used their government-back loans to expand exports were implicitly considered fit and favored with even further support (Song, 1990, 101-2).

The debate between the old (free market) conventional wisdom and the increasingly influential new (statist) conventional wisdom was and remains important to those seeking ways of promoting development in the third world. ${ }^{2}$ However, the sharp exchanges between advocates of these two positions have served to mask some important commonalities. Most importantly, participants on both sides appear to believe that the Korean experience demonstrates that development is possible under capitalism. In fact, they seem to share the belief that capitalism is the only system capable of supporting development. As a result those on both sides have largely dismissed the importance of class and contradictions, as well as the usefulness of Marxism for understanding Korean dynamics.

This celebration of the East Asian experience was finally brought to an end by the 1997-98 economic crisis. The immediate trigger for the crisis was a massive outflow of funds from the region. Foreign investors, increasingly worried about growing banking and trade problems throughout the region, began selling their stocks and bonds, calling in their loans, and converting their local currency receipts into dollars for repatriation. The rush for dollars began in Thailand, and then spread quickly to Indonesia, Malaysia and finally Korea. The governments of these countries responded by sharply hiking interest rates in an attempt to halt the outflows. But, by late 1997, with reserves rapidly shrinking, they were finally forced to abandon their respective pegged exchange rates, leading to a dramatic decline in currency values, and an acceleration of investor flight from the region.

With their economies in free fall from plummeting stock and bond markets, rising interest rates, and rapidly depreciating exchange rates, the governments of Thailand, Indonesia, and Korea reluctantly turned to the IMF, hoping that its support would help restore investor confidence and avert a complete economic collapse. The severity of the economic declines suffered by these countries is captured to some extent by the large contractions in their respective 1998 GDPs: -13.1 percent

2 See for example Amsden (1994). 
in Indonesia, -6.7 percent in Korea, -7.4 percent in Malaysia, and -10.5 percent in Thailand.

The crisis, and especially its rapid spread throughout the region, caught both neoliberals and statists by surprise. Neoliberals had continued to praise the East Asian countries for their market-based policies right up to the very moment the crisis exploded in summer 1997. For example, Jeffrey Sachs, writing in December 1997, commented as follows:

Consider what the Fund said about Korea just three months ago in its 1997 annual report. "Directors welcomed Korea's continued impressive macroeconomic performance [and] praised the authorities for their enviable fiscal record." Three months ago there was not a hint of alarm ... In the same report, the IMF had this to say about Thailand, at that moment on the edge of the financial abyss. "Directors strongly praised Thailand's remarkable economic performance and the authorities' consistent record of sound macroeconomic policies" (Sachs, 1997).

However, once the extent of the crisis became clear, the neoliberal establishment made a complete about face. It now claimed that the crisis was long overdue because the massive state involvement in East Asian economies had led to cronyism and inefficient resource allocation. In fact, the Managing Director of the International Monetary Fund, Michel Camdessus, went so far as to say:

In the less distant future, growth can be expected to rebound strongly after a relatively short, but sharp, weakening of economic activity and a rapid narrowing of external deficits. And as this process takes place, each of these countries will have the opportunity to strengthen its economy in fundamental ways. That is why I am confident that, after this period of adjustment, these economies will emerge stronger than before. Indeed, I believe that this crisis could be a blessing in disguise (Camdessus, 1997, emphasis added).

The adjustment the IMF had in mind amounted to a full scale restructuring of the very economies that neoliberals (including those employed by the IMF) had previously touted as exemplars of market efficiency. For example, when asked at a press conference whether it was possible to reform the Korean "system of industrial policy," the IMF's Deputy Managing Director, Stanley Fischer, replied: “I don't think [the necessary] restructuring would be possible within the Korean model. What has happened in Korea is a breakdown of economic relations caused by that system - the banks were being used to funnel money from abroad into corporations that were not being subjected to market discipline and whose financial structures were not clear" (International Monetary Fund, 1997, 387). The IMF's Managing Director was even clearer. According to John Cathie, "Camdessus, using a literary metaphor from the Spanish poet Miquel de Unamuno (who 'used his ideas as he did his boots; he wore them out and then threw them away'), urged Korea to scrap its development model and begin afresh" (Cathie, 1997/1998, 21).

Although shaken by the crisis, statists disagreed with the hastily constructed neoliberal claim that the crisis was caused by too much state involvement. In fact, they believed that the crisis was largely the result of governments mistakenly 
abandoning their systems of state planning and regulation in the years preceding the crisis under pressure from the IMF and other advocates of liberalization. Therefore, they continued to defend the developmental state as the only instrument capable of achieving sustainable growth. As a case in point, Crotty and Lee, advocates for the statist position, offered the following explanation for the Korean crisis:

There is an alternative interpretation of recent events in Korea, whose adherents include numerous heterodox scholars . . . along with a few prestigious mainstream economists such as Joseph Stiglitz, former Chief Economist for the World Bank, and Harvard's Dani Rodrik. These authors argue that the major cause of the crisis was not inherent inefficiencies in the structure of the Korean development model, but rather contingent inefficiencies created by liberalization, especially in the 1990s. This liberalization process disastrously weakened the structural integrity and coherence of the traditional Korean economic system. In this view, the problem in the 1990s was not too much state intervention, but the cessation of government functions essential to efficiency within the Korean model. In particular, absent the drastic weakening of the government's traditional regulation of short-term capital inflows in the 1990 s, there would have been no systemshaking financial crisis, no IMF takeover, and no radical neoliberal restructuring (Crotty and Lee, 2004).

Perhaps not surprisingly, Korea has become the main intellectual battleground for the continuing struggle between advocates of the old and new conventional wisdoms. As we have seen, Korea was perhaps the most celebrated of all the East Asian success stories. It also employed state industrial policy more extensively then did the other countries. Thus, neoliberals were especially eager to discredit its past experience and take advantage of the crisis to impose a major structural transformation upon it. For the same reasons, statists have focused their efforts on defending the Korean growth strategy and arguing against neoliberal demands for the country's restructuring.

Unfortunately, there is little of value in this ongoing intellectual battle for those Koreans struggling to overcome the devastating consequences of their country's economic crisis. The main reason is that both sides have flawed understandings of the capitalist dynamics that shaped Korea's past growth and more recent crisis. The problems with the neoliberal perspective are numerous and far greater. Neoliberals clearly misrepresented the Korean experience in the pre-crisis period. They had falsely claimed that Korean growth demonstrated the virtues of relying on the market. Statists always displayed a much more accurate understanding of the critical role state direction and regulation played in achieving that growth. Neoliberals then responded to the crisis by abandoning their previous position and arguing that the crisis was a logical consequence of past statism. However, this change in argument has driven them into a theoretical cul-de-sac.

Neoliberals have acknowledged Korea as one of the few third world success stories. By now admitting that the country's past growth was largely due to the efforts of a developmental state and not market forces, they undercut their current argument that markets are the only vehicle for development. In fact, they can offer 
no satisfactory explanation for why statism was able to achieve such sustained and high rates of growth, or what caused it to come to such a sudden end (Burkett and Hart-Landsberg, 2000, Chapter 13). More generally, if the only countries to have succeeded over a sustained period of time were guided by statist policies, then there is little reason to believe that privileging market forces will have beneficial results. Such theoretical twists and turns make clear that neoliberal arguments and policy pronouncements are first and foremost designed to provide ideological cover for (transnational) capitalist interests, interests that run counter to those of Korean (and other) working people.

However, the statist position also is vulnerable to criticism. In particular, even though advocates have a more accurate appreciation of the pre-crisis Korean experience, their own perspective on that experience - including the causes of the crisis, and the policy responses necessary to overcome it - is also seriously flawed. For example, statists tended to celebrate Korean growth without proper appreciation of the costs working people paid for it. Dismissing the class dimension of the Korean growth process is a serious mistake. Among other things, it caused them to downplay the significance of the major struggles that working people waged against the dictatorship and the chaebol dominated export orientation of the economy, struggles which did threaten the continued profitability and viability of the Korean growth strategy. And it also encourages them to imagine that working people would welcome a return to that growth strategy if it were possible.

In addition, statists still do not appreciate the historically specific conditions that enabled Korean growth to take place. Said differently, their embrace of the developmental state was largely built on the assumption that capitalism provides a supportive environment for development if the appropriate state industrial policies are implemented. In fact, statists generally believed that other countries could enjoy Korea-like successes if they adopted Korea-like policies. This view of capitalism as a stable and growth supporting economic system is a false one. And, because of it, statists were unable to grasp the changing dynamics of capitalist accumulation that eventually led to the East Asian crisis more broadly and the Korean crisis more specifically. Given their assumptions, statists were left with only one explanation for the crisis, that it must have been caused by a series of foolish government decisions to abandon a workable strategy of development.

Korea is now undergoing a major neoliberal restructuring process that was shaped by the IMF, under United States (US) direction, with the support of the large chaebol and the Korean state. This process has left statists in full retreat. They cannot satisfactorily explain why the state they counted on to lead the development process is itself implementing neoliberal policies. And with the triumph of the neoliberal position, statists have found little ground for their policy proposals, which are largely directed towards rejuvenating the state directed growth model of the past.

The simple truth is that both neoliberalism and statism are seriously flawed theories of capitalism and as a result unable to illuminate either the Korean experience or provide meaningful perspective on what is to be done to help defend working class interests in Korea. To highlight the superiority of a Marxist approach, we 
offer next, in broad brush, our own Marxian influenced understanding of the Korean experience.

\section{The Dynamics of Growth}

Korea's rapid growth over the period 1961 to 1997 is best explained by a combination of domestic and international factors. Domestically, the Korean state (a military dictatorship) played the central role in shaping the country's economic trajectory. Control over the country's financial system was perhaps the single most important factor enabling the state to successfully direct the economy. Government planners were able to use their control over the allocation and cost of capital to both promote favored producers and regulate firm activity.

By the mid-1960s, the government had decided on exports as the priority activity for all firms. Significantly, this export orientation was generally advanced as part of a comprehensive effort at national industrial development. The government regularly targeted new areas for development by encouraging the establishment of importcompeting domestic firms. These new firms were protected by both trade restrictions and limits on foreign direct investment and, when judged capable, required to export as well as meet domestic needs.

A prime example of this strategy was the government's 1973 program to establish new heavy and chemical industries for both import-substituting and exportgenerating purposes. The government directed firms into these targeted areas with, among other things, subsidized capital. Subsidized loans grew from approximately 30 percent of total credit over the $1965-70$ period, to over 43 percent over the 197175 period, to an estimated 80 percent of manufacturing loans in 1978 . One measure of the government's success: the export share of these heavy and chemical industries rose from 13 percent in 1970 to nearly 60 percent by 1985 (Hart-Landsberg, 1993, 38).

The government was also not hesitant about undertaking key investment activities itself through public enterprises, as in the case of petroleum, chemicals, and iron and steel. It eventually decided, as part of its heavy and chemical industrialization program, that production should be primarily carried out by private firms. It therefore selected a small group of chaebol to dominate production of the new industries. The combined sales of the top ten chaebol relative to GNP soared from approximately 15 percent in 1974 to over 67 percent by 1984. By 1988, the combined revenues of the top four chaebol equaled approximately 47 percent of Korea's total GNP (HartLandsberg, 1993, 38).

This industrial strategy was underwritten in large part by labor exploitation. The dictatorship kept workers disorganized and on the defensive for most of the 1960s and 1970s through its control over the only legal labor federation, a maze of ever more restrictive labor laws, and increasingly violent interventions into labor disputes by the Korean Central Intelligence Agency and special labor police. Government efforts to contain growing labor militancy in the 1980s were expanded to include 
mass arrests of, and several major military assaults against, workers. Also revealing of the nature of the growth regime was that the country's celebrated "economic progress" never brought the state or its growth strategy popular legitimacy. In fact, quite the opposite was true; the dictatorship found it repeatedly necessary to intensify its repression in order to sustain the conditions needed for accumulation.

As important as these domestic factors were, the reality is that Korea's growth also depended heavily on favorable international conditions. More specifically, Korea's rapid industrial transformation received substantial support from both Japan and the United States. Park Chung Hee, the military dictator who ruled the country, had been an officer in the Japanese military during the period when Japan had colonized Korea. Japan was eager to reassert its influence in Korea and thus eager to see him succeed. Therefore, as part of the 1965 Japan-Republic of Korea (South Korea) normalization treaty, Japan gave Korea \$200 million in public loans, $\$ 300$ million in grants and at least $\$ 300$ million in commercial credits. Hundreds of millions of dollars of additional loans and grants followed over the rest of the decade (Hart-Landsberg, 1993, 145). These funds helped Korea finance needed imports and sustain its rapid rates of growth.

The US government provided even greater financial assistance, hoping to strengthen the Republic of Korea in its ideological and military contest with the Democratic People's Republic of Korea (North Korea). One avenue for the resource transfer was Korea's participation in the US led war against the people of Vietnam. The US paid secret dollar bonuses to Korean soldiers, which generated remittances of $\$ 185$ million over the period 1965-73. Almost \$1 billion dollars more was earned over the same period from military and civilian activities carried out in Vietnam and through increased exports to Vietnam. An additional $\$ 1.1$ billion was earned thanks to US military activities in Korea itself, including local spending, provision of goods, and construction (Hart-Landsberg, 1993, 147-8).

In the early 1980s, after Korea suffered a major economic collapse, and was in political chaos, the US and Japanese governments again offered critical financial assistance. Two weeks after the Kwangju Uprising had been brutally crushed the U.S. Export-Import Bank finalized terms to extend more than $\$ 600$ million in import credits to the new military dictatorship headed by Chun Doo Hwan. The heads of Chase Manhattan Bank and First National Bank also traveled to Korea to pledge their financial support. Not long after, the Japanese government extended a massive loan of $\$ 4$ billion under exceptionally generous terms (Hart-Landsberg, 1993, 148, 223).

Japanese and US support for Korea was not limited to financial assistance. Japanese corporations provided critical technology and components to chaebol firms, enabling them to rapidly upgrade production and boost exports. For example, during the 1980s, Korean firms depended on Japanese corporations for between 40-60 percent of their machines, 60 percent of their parts, and 50 percent of their licensed technology. The level of dependence was far greater for those firms producing critical higher value added exports, like cars, ships, and electronics (Bello and Rosenfeld, 1990, 114). The additional US economic contribution included 
a willingness to provide open markets for Korean exports. Thus, in 1986, South Korea's first ever trade surplus, totaling $\$ 4.2$ billion, was made possible because of the country's bilateral surplus of $\$ 7.3$ billion with the US.

Thus, it was a combination of "favorable" domestic and international conditions that helped produce the "Korean miracle." In contrast, neoliberal and statist explanations rested almost entirely on the role of the state, with the former deliberately and misleadingly minimizing its importance. Advocates from both schools largely ignored the domestic (class) tensions and contradictions generated by the country's growth strategy, and never grasped the significance (and temporary nature) of the wider international capitalist dynamics that supported Korean growth.

\section{The Contradictions of Growth}

The late 1980s marked the highpoint for the Korean economy. From 1986-89, the economy recorded annual rates of growth of over 12 percent and its first trade surpluses. But, at the very moment when statist promotions of the Korean model were receiving their most favorable response, tensions and contradictions generated by the country's growth strategy were beginning to destroy the viability of that strategy.

For example, decades of growth had helped the chaebol grow increasingly powerful. They were now able to take advantage of their export successes to weaken state control over their actions. They used their new independence to channel their profits into more lucrative speculative activities rather than productive investments. In addition, the country's rapid industrialization, by creating large working class cities and massive industrial enterprises, also helped to create the necessary conditions for labor solidarity and an explosion of working class activism. Massive strike waves swept the country in 1987 and 1988, resulting in significant wage increases for most manufacturing workers.

International trends also proved threatening to the Korean growth strategy. For example, capitalist dynamics eventually generated tensions between Japan and the US that reached a boiling point in the mid-1980s. In September 1985, under US pressure, the Japanese government agreed to support a rise in the yen relative to the dollar as part of the Plaza Accord. The yen appreciated by almost 50 percent over the period 1985-88, creating serious economic problems for Japanese corporations. Initially, Korean exporters were able to take advantage of the appreciation of the yen to increase their own sales in the US market. In fact, while the yen was rising relative to the dollar, the Korean government engineered a decline in the value of the won relative to the dollar. As a result, although the Japanese trade surplus with the US leveled off in 1987, the U.S. trade deficit with South Korea grew substantially over the years 1986-89.

In response, the US turned its attention to Korea, demanding changes in the country's currency and trade policy. Under pressure, the Korean government allowed the won to rise by 16 percent relative to the dollar in 1988 and by another 3 percent 
over the first half of 1989. The US also threatened Korea with trade penalties if it continued to block imports of US goods through special taxes and tariffs. The Japanese, angered at losing market share to Korean exporters, also took action. For example, "in 1990, the Japanese government decided to ban the export of 200 ultramodern technologies to Korea until 1995" to ensure that "Japanese firms will have exploited much of the market potential of the technologies" (Bello, 1992, 88).

These developments proved disastrous for the Korean economy. The country's trade balance slipped back into deficit beginning in 1990; profits and domestic investment began falling. The government tried to respond, but with little success. It failed to regain control over chaebol activity, in large part because it was now too closely tied to and dependent on them. There was even less it could do to force a change in Japanese or US policy. Thus, it settled on a strategy of attacking labor in hopes of stimulating new chaebol productive investments and exports. But while the working-class movement was weakened, it could not be broken.

These developments also led to a weakening of the Korean planning system. With the state increasingly unable to protect chaebol interests, the chaebol became increasingly unwilling to accept continued state direction and control over their activities. They therefore demanded and won, over the first half of the 1990s, several new freedoms. Among the most important was the ability to borrow and invest internationally without government approval. US pressure also contributed to this outcome. The US government threatened to block Korea's application for admission into the Organization of Economic Cooperation and Development (OECD) unless the Korean government agreed to deregulate and open up the country's financial system (Kristof, 1999).

The international environment grew increasingly hostile for Korea throughout the 1990s. Japanese corporations had responded to the rise in the yen by investing heavily in Thailand, Malaysia, and Indonesia. This investment transformed these countries into major exporters of manufactures that increasingly competed with those produced in Korea, but with even cheaper labor costs (Hart-Landsberg and Burkett, 1998). Transnational corporations searching for even lower cost production opportunities soon flocked to China, turning that country into an even more successful producer of exports. However, one of the consequences of this activity was the regional over-production of cars, steel, petrochemicals, semiconductors, and consumer electronics, which drove down export prices and earnings throughout the region. A case in point: the unit export prices of Korea's heavy and chemical products fell by more than 46.3 percent over the years 1996-98. As a result, South Korea's export growth rate fell from 30.2 percent in 1995 to 3.8 percent in 1996 (Grilli, 2002, 182).

Korea began running bigger current account deficits and accumulating greater foreign debt. Its current account deficit rose from $\$ 4.5$ billion in 1992 to $\$ 8.9$ billion in 1995 , and then to a record $\$ 23.7$ billion in 1996. Chaebol profits were also forced downward: the forty-nine largest business groups recorded total profits of just $\$ 32$ million on combined sales of $\$ 274$ billion in 1996 - a return of just over 0.01 percent (Moon, 1997, 57). Companies sustained their operations largely by going deeper 
into debt. And thanks to the recently approved liberalization policies, an increasing percentage of funds came from foreign lenders. By 1997, South Korea's foreign debt totaled over $\$ 160$ billion dollars, with approximately $\$ 70$ billion due for repayment in less than a year.

The country was teetering on the brink of crisis. Finally, several large and important companies went bankrupt in the first half of 1997. As the financial crisis swept through Southeast Asia, foreign investors became increasingly concerned about the creditworthiness of Korean firms and by extension banks, and the adequacy of the central bank's foreign exchange holdings. As they did in Southeast Asia, they began selling their Korean stocks and bonds and calling in loans. The Korean government responded, as had other governments in the region, by raising interest rates, but it was unable to halt the run on the won; by mid-November, Korea's currency was in free fall and the country was headed into recession and the arms of the IMF.

In sum, the crisis that struck Korea was not caused by misguided liberalization. It was the result of contradictions, internal and external, that made it impossible for the state to sustain the country's growth strategy. Thus, the main lesson from this history is that the crisis that appeared so suddenly in 1997-98 was years in the making and structural. There is no way or reason to restore the state-directed, chaebol-dominated, export-led, growth strategy of the past. The changed international environment also means that there are vastly reduced possibilities for other countries to escape underdevelopment through adoption of Korea's past developmental state strategy.

\section{Neoliberal Restructuring}

No one disputes that Korea is now undergoing a massive neoliberal restructuring. While neoliberals celebrate it, both left Keynesian/statists and Marxists oppose it because of its devastating costs for working people. Unfortunately, most progressive academics, inside and outside of Korea, continue to embrace statist understandings of contemporary Korean capitalist dynamics, which have been little changed by the crisis. Tragically, the flawed nature of these understandings makes it much harder to build the class awareness and theoretical clarity necessary to advance a meaningful working class movement of resistance and transformation.

In general, those who embrace the statist perspective - such as Lee and Lee (2002), Chang and Yoo (2002), Chang and Jung (2005), Cho (2004), Crotty and Lee $(2002 ; 2004 ; 2005)$, and Shin and Chang (2005) - believe that the restructuring process is promoting the establishment of a "finance-led accumulation regime". They continue to believe that the pre-crisis Korean economy was basically sound, and that the crisis was primarily the result of the Korean government's mistaken financial deregulation policies. In their view, the post-1997 neoliberal policies imposed by the IMF and adopted by the Kim Dae Jung and Roh Moo-hyun governments have further weakened the hitherto efficient accumulation regime led by a state-chaebol coalition in favor of the "financialization" of the Korean economy and the associated construction of "share-holder capitalism". They believe that this transformation is 
responsible for Korea's low growth, stagnating investment, social polarization and financial dependence and call, in opposition, for the revival of Keynesian financial repression (including capital controls) and reform of chaebol-corporate governance as well as separation of industrial capital from financial capital.

As explained above, we believe that the crisis was the result of deepening contradictions in the state-capitalist accumulation regime that date back to the late 1980s, not the financial liberalization that immediately preceded the crisis. We also reject statist claims that the Korean economy is being transformed into a new, finance-led accumulation regime. Rather we believe that the post 1997 neoliberal restructuring represents little more than a capitalist offensive designed to restore profitability through the intensified exploitation of the Korean working class.

The structural nature of the crisis is clearly revealed in the trend of the average rate of profit for the economy as a whole, one of the most important Marxist indicators of the health of a capitalist economy. ${ }^{3}$ For Korea, the rate of profit of the non-agricultural business sector, measured by the ratio of pre-tax profits to the net fixed capital stock, fell from approximately 12-14 percent over the period 19701986 to just 5.1 percent (the lowest level since 1970) in 1996, the year before the "official" start of the crisis (Jeong, 2005). Although the profit rate has recovered, as of 2002, it was still at the relatively low level of 6.6 percent, which appears to indicate that the Korean economy has yet to fully recover. Indeed, the average rate of GDP growth was only 4.2 percent from 1998-2004, significantly lower than the 7.1 percent average for the years 1993-97.

Some left Keynesians (Crotty and Lee, 2004; Chang and Jung, 2005; and Shin and Chang, 2005), have challenged the argument that the crisis was structural in nature by citing government data that shows corporate "operating profits" as a percent of sales remaining stable through 1995. This, they claim, shows that the crisis could not have been caused by a collapse of real-sector efficiency. They believe that operating profits, which are measured prior to the deduction of interest payments, are a better indicator of real sector efficiency than ordinary profits, which are measured net of interest payments and other factors, because financial payments and financial assets are excluded from the numerator and denominator respectively. It is thus directly influenced only by real-sector variables. While they are right to focus on operating profits, they are wrong to examine the trend of operating profits relative to sales. To evaluate capitalist profitability properly, profits should be measured against the invested capital stock. Doing so produces the downward trend highlighted above.

As noted above, most left Keynesian/statists - for example, Crotty and Lee (2004) and Chang and Yoo (2002) - also believe that the post-crisis neoliberal restructuring is leading to the consolidation of a new finance dominated accumulation regime in Korea. Because, in their opinion, this "financialization" not only triggered the crisis

3 As Mohun (2004a, 87) said, "(i)n contrast to the neoclassical vision, a theory whose vision is of a society characterized by class conflict over the production and appropriation of the surplus entails that the central category of macroeconomics is not GDP and its components, and their growth over time, but the average rate of profit and its trend over time." 
but is also responsible for current economic difficulties, they call for policies designed to reinvigorate the old accumulation regime. We reject this characterization of the restructuring process as well as the associated reformist policy recommendations.

According to Crotty (2002), "financialization" is generally defined by the following trends: the hegemony of financial capital over industrial capital, the dominance of direct finance through equity and bonds over indirect finance through banks and the related rise of the principle of "share-holder" capitalism, the increasing debts of non-financial corporations, the growing importance of financial assets over tangible assets for non-financial corporations, and the securitization of household financial assets.

While there appears some empirical support for these trends in the United States (and some other developed capitalist countries such as France), the same is not true for Korea. For example, the ratio of financial assets to tangible assets in the manufacturing sector rose from approximately 40 percent in the 1970 s to 65 percent in the 1980s, but remained at that level through most of the 1990s, and has even decreased slightly since 1997. Moreover, although Korean nonfinancial corporations have always been highly indebted, their total liabilities have become lighter rather than heavier after the 1997 crisis. Indeed, the ratio of total liabilities of nonfinancial corporations to gross domestic product fell from 211 percent in 1998 to 201 percent in 2002 . Looking just at the manufacturing sector, the debt to equity ratio decreased from 396.3 percent in 1997 to 123.4 percent in 2003, while the ratio of equity to total assets more than doubled over the same period, from 20.2 percent to 44.8 percent (Bank of Korea, Financial Statement Analysis).

Moreover, there is little to indicate that Korea is undergoing a securitization of household assets. The financial assets of Korean households are overwhelmingly composed of bank deposits. In fact, their share of total financial assets has increased from 42.8 percent in 1975 to 60.3 percent in 2003 . Conversely, the share of equities in total household financial assets decreased from 17.2 percent to 5.8 percent over the same period. There is also little reason to believe that nonfinancial corporations have fundamentally altered their methods of finance away from bank loans towards direct issuance of equity. Although direct finance, especially stock issuance, did increased rapidly after the 1997 crisis, its overall share in total finance for nonfinancial corporations was still only 38.4 percent in 2003, which was lower than the 41.6 percent share from indirect finance (Bank of Korea, Flow of Funds). Loans by financial institutions still composed the largest part of the liabilities of nonfinancial corporations (33.1 percent in 2003), despite the fact that the share of stocks did increase after the crisis (from 10.4 percent in 1997 to 19.8 percent in 2003).

Duménil and Lévy (2004) propose related but different criteria for testing the hypothesis of "financialization." According to them, "financialization" occurs when the share of profits going to interest and dividends is growing, and the financial profitability of nonfinancial corporation, i.e., the rate of profit, considering the financial relations, converges to its real profitability, i.e., the rate of profit abstracting from the financial relations. Again we see little to support this hypothesis for Korea. For example, the ratio of financial outflow - that is, the sum of interest, dividends 
and rents relative to the operating profits of nonfinancial corporations - has remained generally stable at 50 percent since the 1980s. While it did skyrocket to 103.1 percent in 1998, it soon fell back to its long term trend (55.2 percent in 2001). More generally, interest rates have remained low in the post-crisis period: after soaring to 28 percent in early 1998, the call rate of the Bank of Korea fell steadily down to as low as 3.5 percent in mid-2004.

Finally, Korean manufacturing financial profitability has remained substantially lower than real profitability. In other words, in the so-called Korean "high-debt model"4, the financial profitability of the nonfinancial corporation has generally been lower than real profitability due to a constant financial outflow, especially in the form of interest payments. In other words, contrary to the "financialization" thesis, the drain of profits from the real sector to the financial sector has been an intrinsic and constant tendency of the Korean economy. In short, in their desire to champion Korea's past accumulation regime, left Keynesian/statists mistakenly transformed an exceptional and transitory phenomenon into a structural and long-run trend.

The Korean economy did emerge from its crisis more rapidly than did other crisisstricken East Asian economies. However, the recovery of capitalist profitability was largely due to an increase in the share of national income going to profits, or said differently, an increased rate of exploitation. The profit share of the manufacturing sector rose from 21.4 percent in 1996 to 37.8 percent by 2000. In other words, the Marxian rate of exploitation almost doubled (Jeong, 2004).

This intensification of exploitation is reflected in the reversal of hitherto favorable trends for the Korean working class, such as an increasing wage share of national income, decreasing income inequality, a reduction in work hours, decreasing use of irregular workers, and the securing of employment through internal labor markets. For example, the wage share rose steadily from 41.1 percent in 1970 to a peak of 63.4 percent in 1996 ; it was down to 58.8 percent in 2004 . Income inequality among urban households fell until the mid-1990s, and then rose sharply after 1997. In particular, the ratio of the income of the top 20 percent to that of the bottom 20 percent of urban wage earners rose from 4.42 in 1995, to 5.22 in 2003, and 5.43 in 2005. Average working hours per week declined from 54.7 in 1986 to 46.1 in 1998, and have once again begun to increase. Finally, employment security has been severely weakened as a result of the aggressive labor market flexibilization pursued by Korean capital and the state in the aftermath of the crisis. The number of irregular workers, counted as the sum of temporary and daily workers, jumped from 5.4 million in 1995, to 6.97 million in 2000, and 7.27 million in 2005. Approximately half (47.9 percent) of all wage workers now have irregular status. They are paid, on average, only 50.9 percent of the hourly wages paid to regular workers, despite the fact that many were previously regular workers and continue to perform the exact same tasks (Kim, 2005).

4 For more discussion of the Korean "high debt model," see Wade and Veneroso (1998). 
Left Keynesian/statists tend to blame neoliberal financialization for Korea's growing social "polarization" (now a buzz word in Korea), thereby identifying the problem with a particular state strategy rather than capitalism itself. Chang and Jung (2005) even go so far as to deny that the rapid growth achieved during the Park Jung Hee regime was underpinned by extreme worker exploitation and generated its own significant structural polarization through its promotion of a chaebol-driven, exportled growth process. Crotty and Lee (2005) advance a similar argument, claiming for example that "what is needed now are ... policies ... designed to modernize the state-guided system that achieved the thirty five year Korean economic 'miracle'." Although unintended, this perspective plays directly into the hands of an increasingly popular "New Right" movement that is aggressively promoting the virtues of the viciously anti-democratic, anti-left, Park dictatorship.

Beyond the short run costs highlighted above, by systematically intensifying the country's (financial and real) external dependence, the long term consequences of Korea's ongoing neoliberal restructuring will prove even more devastating for working people. Markers of the country's deepening financial dependence include: (1) a rapid increase in the market value of foreign owned shares of Korean corporations, (2) a rapid increase in foreign direct investment, and (3) a rapid increase in the outflow of value from Korea. First, the share of market value owned by foreigners jumped from 13 percent in 1996 to 40.1 percent in 2003; this is the fourth highest in the world, trailing only Hungary (72.6 percent), Finland (55.7 percent), and Mexico (46.4 percent). More specifically, as of June 2004, foreigners owned 58.1 percent, 55.3 percent, and 70.1 percent of the outstanding shares of Samsung Electronics, Hyundai Motor, and POSCO, respectively. The growth of foreign ownership in the financial sector is especially striking, with the foreign ownership share of the eight largest urban banks growing from 12 percent in 1998, to 39 percent in 2003, and 64 percent in late 2004. ${ }^{5}$ Crotty and Lee (2005) describe the consequences of this development as follows:

The rising power of foreign financial firms contributed to investment stagnation, a dramatic increase in household indebtedness, and the conversion of Korea's stock and foreign exchange markets into global gambling casinos. Giant global banks are poised to complete their conquest of Korea's banking market, which means continued problems for investment finance, an increasing disconnection between banking profits and economic prosperity, and tightening constraints on more effective or progressive government policies.

5 By mid-2005, the share of foreign ownership in major Korean banks was 74 percent for Korea Exchange Bank, 100 percent for Korea-America (owned by Citibank), 100 percent for Korea First (owned by Standard Chartered), 76 percent for Hana, 84 percent for Kookmin, and 63 percent for Shinhan (Crotty and Lee, 2005). According to Crotty and Lee (2005), "by mid-2005, Korea had higher foreign bank ownership than almost all Latin American countries. ... the foreign share of all bank assets, including public banks, is about 60 percent. However the share for private commercial banks is about 80 percent in 2005." 
Second, the inflow of foreign direct investment increased rapidly, especially after 1997. It jumped from $\$ 0.8$ billion dollars in 1990 to as much as $\$ 15.5$ billion in 1999 , before falling dramatically to $\$ 2.7$ billion in 2003 . Most of this investment was for mergers and acquisitions of existing Korean companies, many of which were purchased at fire sale prices because of the crisis (Hart-Landsberg and Burkett, 2001, 422)

Third, the outflow of value from Korea - estimated as the sum of royalty payments, interest payment and profits remittance - also increased rapidly, from $\$ 4$ billion in 1994 to \$11 billion in 1998 and higher in the following years. Consequently, the ratio of the outflow of value to GNP reached 2.3 percent in 2001. If we include capital gains, the total outflow of value would be far larger (Jeong, 2004). Indeed, some foreign private equity firms, such as Newbridge Capital and Lone Star, have made astronomical profits by exploiting their "fire sale" purchases of Korean assets after the 1997 crisis.

Key signs of the growing economic dependence in the real sector include: (1) the increased dependence on exports for growth, (2) weakening inter-industrial linkages, and (3) the increased dependence on imported means of production. First, the ratio of exports to gross domestic product has increased from 27.9 percent in 1996 to a high of 44 percent in 2004. Thus, Korea's growth now depends more heavily then ever on exports, a growing share of which is tied to the fortunes of the US information technology sector. Significantly, while the relative importance of exports has grown, investment has been stagnating. In fact the investment to gross domestic product ratio has fallen from 37.5 percent in 1996 to 29.5 percent in 2004 (Jeong, 2004). If overinvestment was a partial cause of the 1997 crisis, underinvestment is now a major concern, one which suggests that the revival of chaebol profitability has little to do with the restoration of a healthy regime of accumulation.

Second, exports are becoming increasingly import dependent. Indeed, the coefficient of production, (calculated as the increase of production generated by a unit increase in exports) has fallen from 1.99 in 1990 to 1.87 in 2002, while the coefficient of imports (calculated as the increase of imports generated by a unit increase of exports) rose from 0.28 in 1993 to 0.37 in 2000 (Bank of Korea, Input-Output Tables). These trends strongly suggest the weakening of inter-industrial linkages, in particular the creation of a dual economy with a dynamic import-dependent (IT/chaebol) export sector and a stagnating domestic (non-IT/ small and medium companies) sector. Third, the ratio of imported means of production to total consumed means of production, a critical indicator of the degree of economic dependence, has also been increasing. Specifically, the dependence on imported parts for private fixed capital in the manufacturing sector has increased from 31.3 percent in 1993 to 42 percent in 2000 (Bank of Korea, Input-Output Tables). This dependence can only be expected to grow if the state "successfully" completes the series of Free Trade Agreements including one with the US that it is currently negotiating.

The reluctance of left Keynesian statists to take a critical stance toward capitalism has forced them to create a variety of capitalist categories which are then labeled either good or bad. Thus, Korea's old industrial based accumulation regime is good 
and worthy of defense. Korea's new finance based accumulation regime is bad and must be opposed. Polarization and dependency become characteristics of the latter rather than central tendencies of capitalism itself. This stance not only mystifies the causes of the crisis, it also weakens the development of the class consciousness necessary to build a movement capable of overcoming and transforming capitalism. In fact, this stance actually encourages working class support for various rightwing movements that seek to bring back the regressive and repressive social structures and policies of the past.

Left Keynesian/statists gained a significant measure of popularity during Korea's period of rapid growth, and largely because of it. While greatly reduced because of the crisis, this popularity still gives them considerable influence over the strategic thinking of working class and intellectual activists and by extension the political orientation of those resisting the deteriorating working and living conditions experienced by most Koreans. Having dismissed Marxism and socialism as largely irrelevant, left Keynesians have little to offer activists except variants on TINA (There is no alternative - to capitalism) which shift back and forth between various "good," "consensual," "self-reliant," and "national" models of capitalism such as German, Swedish, Dutch, and Danish, etc. Indeed, the maximum goal for left Keynesian/statists appears to be the achievement of "progressive competitiveness" based on "high-road" (high skill and high tech) production techniques supported by government subsidy of education and training etc. This type of thinking has even led some left Keynesian/statists (for example Chang and Jung, 2005, and Shin and Jang, 2005) to defend the chaebol system on the grounds that it provides an attractive alternative to a foreign capital takeover and can serve as a foundation for strengthening the "national economy" and "stake-holder" capitalism.

Missing from this political project is any recognition of the class and contradictory logic of capitalism, embrace of a labor and class perspective, and equally important, post-capitalist imagination. And, these are precisely what must be encouraged if Korean working people are to successfully confront capitalism's restructuring process, which continues to proceed at their expense. Said differently, the task of critiquing and transforming capitalism is far from out of date; Marxism needs to be reclaimed and the socialist project renewed.

\section{The Retreat from Marxism in the Development Debate}

While we have concentrated on demonstrating the continuing relevance of Marxism for understanding and responding to developments within Korea, the Korean situation is far from unique. In fact, given that the Korean example has often been used to support left Keynesian/statist policies elsewhere we believe that the arguments made above have a wider significance. At the same time, the marginalization of Marxism as a vehicle for understanding Korean processes and struggles cannot be understood as simply a Korean phenomenon. Rather it is a reflection of broader theoretical tendencies within the social sciences. Thus, it is absolutely critical to address the 
question of why Marxism as an analytical paradigm came to be dismissed, if not rejected, by most contemporary progressive academics (within and without Korea), thereby allowing the development debate (especially as it concerned the Korean experience) to be reduced to the arid spat between neoliberalism and statism as described above.

Answering this question requires that we take a step back to track the "development" of development theory itself, starting in the period following World War 2 (WW2). In the 1950s, as the "formalist revolution" (Blaug, 2003) swept neoclassical economics to an unrivalled hegemonic position in AngloUS academies, it was hardly surprising that the theorizing of development would commence under the spell of neoclassical ideological assumptions. "Modernization theory", as the formative approach to the field was dubbed (Randall and Theobald, 1998), held market society (what we refer to as capitalism) to be the telos of human history. Accordingly, the rapidly de-colonizing world, dominated by "backward" or "traditional" societies, had only to adopt market economic organization and sociopolitical patterns of dominant capitalist states in order to progress in a relatively frictionless fashion toward "modernization" in the image of those capitalist states. This modernization process was to be advanced across the globe by marketbased trade organized according to the principles of "comparative advantage". In international practice that meant that developing states were encouraged to specialize in the production of those goods in which they had purported factor endowment advantages, essentially primary products and light manufactures.

However, by the mid 1960s, mounting evidence from across the third world indicated that the policies encouraged by modernization theory were not leading to anything remotely resembling development as experienced by the advanced capitalist states. Prices for primary products, which modernization theory claimed would rise and contribute to global factor price parity as a result of expanding demand from industrialized countries, actually fell steadily in the post war period. This occurred in part because many industrialized countries, especially in Western Europe and North America, were now generating huge surpluses of foodstuffs. Many were also successfully engineering synthetic replacements for leading third world primary product and agricultural exports. Moreover, when development along capitalist lines did occur, it tended to be concentrated in economic sectors tied to foreign export, leaving large swaths of the third world disconnected from those growth processes and increasingly impoverished.

In response to this anomalous state of affairs, a genre of scholarship best described as "critical" international political economy emerged under the rubrics of theories of "dependency," "unequal exchange," and "world-system". 6 Scholars associated with these theories were generally inspired by Marx's analysis of the ways in which the plunder and colonialism of the third world contributed to the "primitive accumulation" of early West European capitalism as well as his

6 On the general conceptual thrust of this scholarship see Brewer (1991); Kiely (1995). 
revolutionary commitment to eradicating exploitation. At the same time many were critical of Marx because of their mistaken belief that Marxism held that this process of primitive accumulation would eventually spread capitalist industrialization and development across the globe.

These dependency-type approaches put forward radical critiques of modernization theory that contained several shared assumptions: Firstly, they sought to anchor the study of development within understandings of the world-systemic economic logic of capitalism. This logic, activated in the $16^{\text {th }}$ and $17^{\text {th }}$ century expansion of capitalism from its West European heartland, not only engendered class division and significant social inequalities in national contexts as Marx had made clear but, through world economic interaction between "core" and "peripheral" states, yielded economic outcomes in the latter qualitatively different from what capitalism produced in the former. Not development, but rather, underdevelopment followed, and this underdevelopment of the periphery was a factor in the accelerated capitalist development of the core.

Secondly, it was this divergent economic outcome of core/periphery relations, described variously as "dependent", "extroverted", "disarticulated", and so forth, that dependency-type theories argued modernization theory misinterpreted as backwardness. Third, these theories also argued that so-called free trade between core and peripheral states, played out according to the tenets of comparative advantage, operated with a wage related inequity in relative prices for core manufactured goods over peripheral primary and lower value-added manufactured products to transfer wealth from the periphery to the core. Fourthly, these theories maintained that if peripheral economies were to develop in an "introverted", "auto-centric" fashion, they had no choice but to "de-link" from the world economy and construct their economies through import-substitution industrialization (ISI), possibly even as socialist economies. Dependency-type theories thus placed a spotlight upon the role of the state as the organized force of development policy direction.

This "critical" approach was also popular in Korean progressive academic circles in the late 1970s and early 1980s. One reason was that such dependencytype theories, especially those Westernized variants influenced by the work of Andre Gunder Frank and Samir Amin, provided a disguised, and therefore safe, way for Korean progressives to engage in radical research during a time when military dictatorship made it illegal to even read Marx or Lenin. Even Park Hyun-Chai's celebrated work, Theory of National Economy (1978), could be regarded as a variant of dependency theory.

Despite resonating with much of the overt reality of colonialism and imperialism, these critical theories were themselves challenged from several directions. A genre of "structuralism" argued that they focused far too much on circulation and exchange relations in the world economy while devoting scant attention to substantive economic relations or "modes of production". Concentrating on the latter, according to this perspective, reveals that the taproot of underdevelopment is not simply

7 See Kiely (1995, Chapter 4). 
trading relations between core and peripheral areas in a capitalist world-system but the economic articulation of capitalist and non-capitalist modes of production. Put differently, structuralism maintained that the expansion of capitalism highlighted in world-systems theory did not necessarily engender capitalism everywhere. Therefore, the challenge for development studies in the view of structuralism is to analyze underdevelopment as the result of the particular historical modalities by which capitalism variously conserves, dissolves or even conjures up non-capitalist modes of production through its global expansion. Thus, development studies should examine more closely the class structures and class alliances of underdevelopment in both the national and international dimensions of social class.

Another challenge came from a so-called "orthodox" Marxism that drew onesidedly from Marx and Lenin's writing to promote the view of imperialism as the "pioneer" of capitalism. Bill Warren, the leading proponent of this perspective, questioned the dependency-type project as a whole. Warren (1980) argued that not only would the expansion of capitalism from its heartlands ultimately decompose pre-capitalist socio-economic relations, but there was mounting evidence to support the reality of third world industrialization and development (no matter how delayed). In making his argument, Warren voiced his agreement with Marx's position on the ravages visited on the world through the primitive accumulation of capital. He also claimed agreement with Lenin that, while imperialism was bellicose and predatory, the export of capital it fostered expanded the productive forces in the peripheral states such that the logic of capital and capitalist development would ultimately prevail.

Warren's argument, however, was subject to ruthless criticism on many grounds including that despite his use of radical terminology he was doing little more than repackaging neoclassical modernization theory. He was also attacked for his quick and shallow reading of the evidence, which showed that although industrialization in peripheral states, particularly in Latin America, did occur through ISI, it continued to face obstacles caused by its inability to support the expansion of the home market, which consistently limited its overall thrust. ${ }^{8}$

This so-called "orthodox" Marxist approach also drew support in Korea. Some Warrenite scholars, such as Ahn (1986), intoxicated by Korea's rapid economic growth and increasing chaebol autonomy, even declared that "dependency is dead, long live Korean capitalism!" The popularity of this approach in Korea reached its peak in the late 1980s, which as we saw above proved to be the zenith of Korean capitalism. Significantly, many of the advocates of this position in Korea eventually became open supporters of capitalism or at best Left Keynesian/statistism.

In the end, Marxism appeared to coalesce around three positions: an "impossibility thesis" of the dependency-type that held development in the third world was forever compromised by the logic of the capitalist world-system; the "inevitability thesis" exemplified by Warren that accepted development in the third world was belated but

8 See Ayres and Clark (1998). 
believed imperialism planted the capitalist seeds of it and capitalist logic would dissolve non-capitalist socio-economic relations; and then there was structuralism which held a more complex, mediating position, maintaining that capitalism would always find ways to link to precapitalist modes of production in ways that would coopt these in order to strengthen capital accumulation at another pole of an economy and cement capitalist dominance over the whole.

As the number of theoretical approaches multiplied, all claiming a somewhat similar Marxist lineage yet all leading to different assessments of on-the-ground realities and possibilities, growing numbers of progressive scholars came to doubt the usefulness of what they saw as Marxist-type overarching or "meta-theoretical" explanations, particularly ones predicated on a supposed inexorable logic of capitalism working its way through history. This, in turn, led a number of them to conclude that development studies animated by Marxism had reached an "impasse" and that Marxism itself had to be abandoned if the field was to regain its relevance. This retreat from Marxism in fact marked a much more pivotal turn in development studies away from development theory as such, at least in the strong sense of the term. As a consequence, development thinking became increasingly supportive of and influenced by post-structural and post-modern approaches (Escobar, 1995; Dirlik, 1997).

This turn towards postmodernism and post-structuralism also became popular in Korea during the 1990s. Progressive Korean scholars began dismissing the grand debates of the 1980s as futile word-mongering. Instead, they turned their attention to the development of specific alternative policies, and emphasized the importance of civil movements, especially NGOs, rather than workers' movements. Many also became attracted to and supporters of the new civilian governments led by Kim Dae Jung and Roh Moo-hyun.

Nevertheless, as the "impasse" debate ran its course, evidence of continuing industrialization in the third world, particularly industrialization in more high value added heavy and consumer durable industries previously coveted by core developed states, fed the desire for a new, more comprehensive or, once again, overarching theory to capture the complex physiognomy of what was first dubbed the new international division of labor (NIDL) and ultimately "globalization" (Hoogvelt, 1997). One response was offered by the regulation school (Aglietta 1979; Lipietz, 1987). This approach argued that analysis of capitalist development requires a "mid-range" theory which studies capitalism at an "institutional" level to capture the way the "contradictions" of capitalism are managed, thereby ensuring successful long-run accumulation across historical periods or stages of capitalism. By embracing the need for "levels" of theory, the regulation approach held out the promise of overcoming the charges leveled against Marxism in the impasse debate. In particular, the regulation school's call for mid-range theorizing involved grasping the discrete logic of accumulation based on the institutional "forms" of each stage. By periodizing capitalism according to the structures of accumulation that marked

9 On the "impasse debate" see Kiely (1995); Westra (2004a). 
each major epoch of capitalist history, regulation theory also appeared to avoid the pitfall of seeing either development or underdevelopment as the inevitable outcome of a single logic of capital.

Regulation theory also offered a new perspective on the major changes underway in the global economy. According to the theory, it was the capitalist stage or "regime of accumulation" of fordism, emanating from the United States, which dominated the regulation of capital accumulation in the core capitalist countries in the period following WW2. The main characteristics of this regime included an institutional ensemble of assembly-line mass production, monopoly forms of competition, high wage and benefit bargains with labor, and Keynesian state demand management.

The theory also held that all regimes of capitalism, including fordism, ultimately fall into crisis. In the case of fordism, the specific crisis was triggered by a profit squeeze that resulted when rising investment costs to meet economy of scale requirements could no longer be offset by intensifying assembly-line work given technical limitations in the labor process. Thus the task fragmentation and functional specialization characterizing key fordist industries became the foundation for spatially separating parts of the production process, thereby enabling capitalists to recoup profits through a globalizing of fordism. Mexico and Brazil became attractive sites for fordist industrial processes because of their proximity to the US market and sizeable working classes. Korea and Taiwan were also chosen as sites because of their disciplined labor forces and colonial legacies, which included the absence of a landed class and presence of an industrial infrastructure.

Despite its provocative conceptual framework and explanation for world economic developments, regulation theory soon found itself at the center of a three-pronged attack. First, it was subjected to criticisms similar to those leveled against Marxism in the impasse debate, that regulation school's theorizing of the internationalization of fordism continued the problematic tendency of Marxism to simply "read off" the development trajectory of the capitalist periphery from the designs of core capitalism (Kiely, 1995). Second, questions were raised about its empirical rendering of East Asian development in terms of fordist institutions. For example, Amsden (1990) claimed that the meteoric economic development in Japan and the East Asian NICs represented not fordism but a discreet "post-fordist" mode of accumulation characterized by a welter of novel labor process innovations and a new capitalist business structure. Finally, it was assailed by some Marxists for not fully developing the potential of its mid-range level of theory (Westra, 1996). That is, regulation theory never elaborated upon the other "ranges" of theory that were supposed to link to its regimes of accumulation and modes of regulation. As a consequence, the conceptual lacuna in specifying the unit of analysis of capitalist development (whether as a congeries of "national" capitalisms or as a single world system) and thus the determination of capitalist trajectories were simply transposed to the mid-range level of theory rather than being satisfactorily addressed.

In Korea, regulation theory was also initially regarded as a promising alternative approach to Korean capitalism by some progressive scholars (Kim, 1988). However, following the general trend elsewhere, many of its advocates became focused on the 
mid-range level of analysis and the regulating aspects of capitalism, and thus drifted towards left-Keynesian/statism. Indeed, it is now rare to find any traces of Marxism in regulation school-influenced scholarship in Korea.

\section{Marxism and Socialist Development}

Paralleling and accelerating the retreat from Marxism in development theorizing was a growing crisis of confidence among progressives over whether socialism was a viable project for developing countries. Marxists generally believed that socialism was to emerge out of the historical development of capitalism, which would create the conditions for it by developing the productive forces of society and the mass working class movement that would overthrow capital. As a result, the political economic milieu of most developing countries, where capitalist development of the productive forces was limited and the working class not a significant force either numerically or politically, continued to pose a challenge to the Marxist strategic perspective.

In this context, the experience and positions of the former Soviet Union (USSR) were influential (Griffin and Gurley, 1985). The Soviet leadership argued that with the consolidation of "socialism" in the USSR, the "highest" historical stage of human development had been reached. Because of the existence of the USSR, other countries were now able to skip the evolutionary path through capitalism as long as they simulated the development of those aspects of capitalism purportedly required by socialism. This, in turn, required the leadership of "Marxist-Leninist political parties" imbued with proletarian class consciousness. This procedure for building "socialism", which characterized most of the "socialist" experiments of the 20th century, became known as "developmental socialism" (Durand, 1990).

Where no socialist revolution was on the political agenda, "socialists" were encouraged to support strategies of so-called "national liberation" in which the working class and its representatives would forge alliances with social classes deemed progressive from the standpoint of "national" capitalism. This strategic perspective meshed well with that promoted by dependency theorists, who advocated a de-linking from the capitalist world system and auto-centric capital accumulation through ISI. Of course, as previously noted, without an expanding home market few if any de-linked states could hope to acquire globally competitive technologies (Ayers and Clarke 1998). And, as the historical record of the oscillations in Latin America between "populist" and authoritarian regimes demonstrated, attempts to expand the home market generated contradictions and highly combustible social class outcomes.

To be sure, Soviet-style regimes suffered from their own structural limitations. While it is true that when comparisons were made in basic social welfare indicators between developing countries striving to construct socialism and developing countries that remained within the orbit of the capitalist world system, the former generally came out best (Navarro, 1992). However, there were other costs borne 
by working people in these "socialist" countries. As we have seen, "developmental socialism" was charged with developing forms of capitalist productive organization in order to build "socialism." The result was often a crude "taylorist" system of work organization coupled with odious modes of authoritarian social control, an outcome that in hindsight appears inevitable given that the logic of the effort required "channeling" capitalism to develop "socialism".

It is within this historical trajectory, with Marxism increasingly wracked by internal debate and "socialism" as a post-capitalist world system teetering on the edge of collapse, that statism arose as the accepted critical opposition to a reinvigorated neoliberalism. Significantly, much of the conceptual accouterment of statism comes from a highly selective and limited engagement with both dependency-type theories and Marxism. For example, the statist eschewing of world economic analysis and focus upon comparative case studies owes much to the increased attention dependency theorists gave to so-called "situations of development" (Cardoso and Faletto, 1979). Similarly the assumed centrality of the state's role in development owes much to the Marxist analysis of the concentrated power and class dimensions of the state and the historical evidence Marxist studies marshaled on the necessary support the state provides to capital accumulation.

Not surprisingly, the statist research program suffers precisely because of its rejection of key tenants of Marxism, including its focus on the fundamental contradictions of capital accumulation and the class distributive social outcomes and crises tendencies that perpetually play themselves out across capital's national and international development trajectories. It is this theoretical shortcoming that allowed left-Keynesian/statists to reify the post-WW2 epoch of so-called "economic nationalism" (Brown and Lauder, 2001), in which the Keynesian welfare state embedded in a world economy of fixed currencies and capital controls constituted the development template. Influenced by this one-sided understanding of capitalism's "golden age", many on the left became convinced that capitalism was amenable to substantive reform and progressive and even socialist goals.

\section{The Necessary Resurrection of Marxist Analysis}

Marxists have, of course, continued to challenge their opponents in the impasse debate. Among other things, they have pointed out how those critical of Marxism have often violated their own purported commitment to "difference" by tarnishing all Marxist-influenced theories with the same brush. They have also objected to the way their opponents have transformed their critique of meta-theories into a broader dismissal of the importance of the categories and insights that inform them (Kiely, 1995). For example, rejection of a particular overarching world-systemic explanatory framework certainly does not lead logically to the conclusion that world systemic analysis per se can or should be dispensed with.

More generally, Marxist efforts to develop mediations between the accumulatory and social class logic of capitalism, on the one hand, and the spatial logic of capitalism 
on the other (the main concern of dependency-type theories), have much to contribute to our knowledge of global capital accumulation and its crises tendencies (Arrighi, 1994; Harvey, 2006). Further, as conceptual categories, the terms core/periphery perdure in analytical force only now capturing the modalities by which core and periphery emerge as potentially geographically indeterminate "social relationships" at the heart of both developed and third world societies (Hoogvelt, 1997).

Though structuralism itself foundered over the impasse debate question of reading underdevelopment in terms of its functionality to global capitalism, the emphasis it placed upon social class and the national and international class dimensions of the capitalist mode of production breaths new life in the theory of "transnational historical materialism". ${ }^{10}$ In fact, the research agenda of transnational historical materialism intertwines several threads of earlier Marxist analysis to offer a potent critique of current globalization. Similarly, the concern of regulation theory with the NIDL and spreading global fordism is refocused by transnational historical materialism into a consideration of the "transnational relations" of US corporate capital and the US ruling class. Here, the work of the Italian Marxist Antonio Gramsci on class hegemony, a conceptualizing of class power deriving from consent rather than overt coercion (though coercion always lurks in the background), is used to examine the class articulations following WW2 that bound ruling classes of Western Europe and Japan to a common reconstructive project under US auspices. Transnational historical materialism is also developing a Marxist analysis of the concentrated power of the capitalist state in terms of the "internationalizing of the state", to capture the ways in which the US capitalist state promoted the international processes leading to the de-regulation and global financial market dominance characteristic of current neoliberal globalization.

While the regulation school's periodizing of capitalism in terms of fordism and its global spread was justly criticized during the impasse debate for its functionalist tendencies, the project of theorizing phases of capital accumulation has emerged as an indispensable tool in many of the most vibrant schools of Marxist thought. ${ }^{11}$ The reality is that the critical assumptions underpinning neoclassical economics - that abstract modeling of economic conditions of "perfect competition" and "general equilibrium" directly yield insights into the complex real world economy, insights that policymakers can confidently follow - have been proved bankrupt again and again, as have their associated policies. By contrast, it appears clear that capitalist history is marked by world historic phases of development, each characterized by a leading economic sector, concomitant technology bundle, geo-spatial core and an institutional/policy architecture supporting market operation. In this sense, the constituents of a phase are the matrix through which capital receives the modicum of coherence it requires for relatively long periods of accumulation.

10 Overbeek (2000) offers a succinct summary of this perspective.

11 Albritton, Itoh, Westra and Zuege (2001) provide an anthology of the important schools of though in this vital area of Marxian research. 
On the question of the post-war phase of capitalism that regulation theory dubbed fordism, debate still continues over what other appellation best reflects its key characteristics and the role to be accorded to particular constituents in guaranteeing the accumulation and expansion of capital. At the same time, there is consensus among the competing theories that global capitalism and the economies of major capitalist states operated with a requisite symmetry up to the early 1970s, at which time the world economy was beset by stagnation and crisis. There also tends to be widespread agreement that the so-called golden age of accumulation reified in statist literature cannot be reinstated, as it was contradictions generated by the capital accumulation process that marked that period which begat the accumulation restructuring associated with neoliberalism in the first place. Questions do remain, however, about whether processes of neoliberal globalization do in fact constitute a new phase of capitalism (Westra, 2003a).

As noted above, the problems development studies faced in reconciling claims for inexorable logical tendencies of capital with evidence of divergent historical outcomes of capitalist development were in part responsible for the turn in development theory away from Marxism and toward post-structuralism and postmodernism. Though the promise regulation theory held out for resolving such theoretical problems was ultimately not fulfilled, this hardly warrants the conclusion that these problems are irresolvable and that Marxists must chose between clinging to a crude determinism or embracing the post-modern play of meaning in the study of local narratives of development.

For example, work influenced by the Japanese Uno approach to Marxism (Westra 1996; 2006) also offers a "levels of analysis" perspective for the study of capitalist development which incorporates mid-range theoretical analysis. However, it develops the mid-range level within the context of the elaboration of other ranges of theory. More specifically, it offers argumentation over the epistemology and role of each level to demonstrate how levels operate within a division of labor to produce knowledge of capitalism. It also maintains that Marx's economic theory of capitalism is not a meta-theory of the sort post-modernism rants against, as its direct subject focus is but a single subset of human social relations - material reproduction - studied under the historically delimited conditions of capitalism, a historically transient society.

Mid-range theory or what the Uno approach refers to as "stage theory" offers a synchronic or structural analysis of the constituents of a phase of capitalism and deals simultaneously with the unit of analysis question as well as the functionalism attributed to Marxism. Said differently, stage theory is neither a theory of national capital nor international capital yet theorizes each synchronically as structures of accumulation for a stage. Historical outcomes cannot be read off stage theory precisely because stages are theorized as structures and are concerned with predominant "types" of capital. And, stage theory in the Uno approach is epistemologically distinct from the level of "historical analysis" which is the empirical, transformatory and agency oriented level of theory that studies the impact of capital's logic on modern history as one determinate force alongside other social forces such as race and gender. 
In Korea, however, Unoist theory never won much of a following. One reason is that although it provided an important critique of Soviet-style "socialism" - arguing that while the USSR de-commodified labor power it reinstated forms of extraeconomic compulsion for work reflective of pre-capitalist societies - its primary contributions to Marxism in the area of the study of capitalism remain highly theoretical. In Korea, Uno influenced scholars have rarely involved themselves in revolutionary praxis. As a result, Unoist theory in Korea is usually regarded as a kind of history of Marxology rather than a living revolutionary Marxist tradition.

Strikingly, the demise of the Soviet-style experiment that led not only opponents of socialism but also some Marxists to accept the premise of TINA has also energized socialists of varying persuasions to rethink the theory and practice of socialism in a new light. Review of this burgeoning literature (Westra, 2001;2002; 2004a) indicates that a plethora of issues at one time believed to interminably compromise socialist aspirations are now being routinely addressed. For example, sophisticated models have been devised which display how computers can contribute to the processing and transmission of economic information with the sort of efficiency once seen as the sole prerogative of markets. Similarly, in response to the discrediting of Soviet-style central planning, Marxists have been forthcoming with new models of democratic, decentralized, participatory planning in which economic decisions are articulated through iterative micro, meso, and macro planning bodies. Acknowledging that the Soviet-style command economy was a highly ineffectual innovator, Marxists have also developed new formulas by which participatory socialist economies can marshal the "tacit knowledge" of society to innovate in the most creative ways that also conform to socialist desires to lessen work alienation. Marxism has also branched out to meet head on "green" critiques of industrial society to demonstrate how Marx's writings capture the anti-environmental thrust of capitalism and point the way to the building of eco-sensitive future socialist societies (Burkett, 1999).

But probably the greatest boost that Marxism and its vision and call for a socialist future could ever receive is the dismal failure of decades of neoliberalism, and globalization under its impetus, to contribute to the betterment of the human condition. In the US, the much vaunted exemplar of neoliberalism, 25 percent of children are born into poverty and an estimated 100,000 are living on the streets. This has been accompanied by a fall in wages for men in the 25 to 34 age group - the period when families are often formed - of 26 percent since 1972 (Anelauskas, 1999, 209, 71). Instead of the advertised world of NICs, neoliberalism has bequeathed a world of NNEs or nonviable national economies and UCE's or ungovernable chaotic entities (De Rivero, 2001). A study cited in the conservative Economist (2005c) names 46 such potentially "failed states". Instead of realizing a middle class dream for humanity, neoliberalism portends a nightmare scenario where it is estimated half of the worlds' urban population will be living in slums and shanty-towns by 2020 (Davis, 2004, 17). And, neoliberalism holds out a bleak future for today's youth with 50 percent of the one billion young people between 15 and 24 already living in poverty (World Watch Institute, 2004, 153). 
As the above makes clear the struggle to replace capitalism remains critical, even in countries like Korea, which are widely celebrated as capitalist success stories. We know well that this is no easy struggle. But, we also strongly believe that socialist intellectuals, working to reclaim and reinvigorate Marxism as part of that struggle, can help promote the class based movements, structural understandings, and new visions necessary to ensure its ultimate success. We hope that in some small way this volume, which attempts to clarify and addresses the challenges facing those struggling for change in Korea, can contribute to that process. 
$\fallingdotseq$ Taylor \& Francis

Taylor \& Francis Group

http://taylorandfrancis.com 


\section{References}

\section{Works in English}

Abegglen, J. (1994), Sea Change: Pacific Asia as the New World Industrial Center, (New York: The Free Press).

Aglietta, M. (1979), A Theory of Capitalist Regulation, (London: New Left Books).

Albritton, R. (1991), A Japanese Approach to Stages of Capitalist Development, (Basingstoke: Macmillan).

Albritton, R. (1999), Dialectics and Deconstruction in Political Economy, (Basingstoke: Macmillan).

Albritton, R. and Simoulidis, J. (eds.) (2003), New Dialectics and Political Economy, (Basingstoke: Palgrave).

Albritton, R., Bell. J., Bell, S. and Westra, R. (eds.) (2004), New Socialisms: Futures Beyond Globalization, Innis Centenary Series: Governance and Change in the Global Era, (London: Routledge).

Albritton, R., Itoh, M., Westra, R. and Zuege, A. (eds.) (2001), Phases of Capitalist Development: Booms, Crises and Globalizations, (Basingstoke: Palgrave).

Alvis, J. (2005). "Korea as A Business Hub in Northeast Asia", Korea Insight 7: 6. Amsden, A. (1989), Asia's Next Giant: South Korea and Late Industrialization, (New York: Oxford University Press).

Amsden, A. (1990), “Third World Industrialization: 'Global Fordism' or a New Model?", New Left Review 182.

Amsden, A. (1994), "Why Isn't the Whole World Experimenting With the East Asian Model to Develop?: Review of World Bank's East Asian Miracle Report”, World Development 22: 4.

Anelauskas, V. (1999), Discovering American as It Is, (Atlanta: Clarity Press).

Aoki, M, Murdock, K. and Okuno-Fujiwara, M. (1998), "Beyond The East Asian Miracle: Introducing the Market-Enhancing View", in Aoki et al. (eds.).

Aoki, M, Kim, H-K and Okuno-Fujiwara, M. (eds.) (1998), The Role of Government in East Asian Economic Development, (Oxford: Clarendon).

Arrighi, G. (1994), The Long Twentieth Century, (London: Verso).

Asian Development Bank. (2004), Key Indicators 2004, May, www.adb.org/ statistics.

Asian Development Bank. (2005), Asia Regional Information Center Indicators. http://aric.adb.org/.

Asian Development Bank. (2006), Asia Regional Information Center Indicators, http://aric.adb.org/.

Athukorala, P. (2003), "Product Fragmentation and Trade Patterns in East Asia", Working Paper 2003/21, Division of Economics, Research School of Pacific and 
Asian Studies, Australian National University, October.

Ayers, R. and Clarke, D. (1998), "Capitalism, Industrialization and Development in Latin America: The Dependency Paradigm Revisited”, Capital and Class 64.

Balassa, B. and Williamson, J. (1987), Adjusting to Success: Balance of Payments Policy in the East Asian NICS, (Washington D.C.: Institute for International Economics).

Ban, S. (1979), "Agricultural Growth in Korea, 1918-1971", in Hayami et al., (eds.).

Baran, P. and Sweezy, P. (1966), Monopoly Capital, (New York: Monthly Review Press).

Barnet, R. and Cavanagh, J. (1994), Global Dreams, (New York: Simon \& Schuster).

Bello, W. (1992), People and Power in the Pacific, (London: Pluto Press).

Bello, W. (1998), "East Asia: On the Eve of the Great Transformation?", Review of International Political Economy 5: 3.

Bello, W. and Rosenfeld, S. (1990), Dragons in Distress: Asia's Miracle Economies in Crisis, (San Francisco, CA: Institute for Food and Development Policy).

Bellofiore, R. (ed.) (1998), Marxian Economics: A Reappraisal, Vol.2, (New York: St.Martin's Press).

Bellofiore, R. (ed.) (1999), Global Money, Capital Restructuring and the Changing Patterns of Labour, (Cheltenham: Edward Elgar).

Berger, S. and Dore, R. (eds.) (1996), National Diversity and Global Capitalism, (Ithaca: Cornell University Press).

Bernard, M. (1999), "East Asia's Tumbling Dominoes: Financial Crises and the Myth of the Regional Model", in Panitch and Leys (eds.).

Bienefeld, M. (1988), "The Significance of the Newly Industrializing Countries for the Development Debate", Studies in Political Economy 25.

Bivens, J. (2004), "Shifting Blame for Manufacturing Job Loss", Briefing Paper 149, Economic Policy Institute, April, http://www.epinet.org/briefingpapers/149/ bp149.pdf.

Blaug, M. (2003), "The Formalist Revolution of the 1950s", Journal of the History of Economic Thought 25: 2.

Bloch, H. (ed.) (2003), Growth and Development in the Global Economy, (Cheltenham: Edward Elgar).

Bloomfield, G. (1991), “The World Automotive Industry in Transition”, in Law (ed.).

Blustein, P. (2001), The Chastening: Inside the Crisis that Rocked the Global Financial System and Humbled the IMF, (New York: Public Affairs).

Bonefeld, W. and Holloway, J. (eds.) (1996), Global Capital, National State and the Politics of Money, (Basingstoke: Macmillan).

Bradley, H., Erickson, M., Stephenson, C., Williams, S. (2000), Myths at Work, (London: Polity).

Bradsher, K. (2005), "Next Wave from China: Exporting Cars to the West," New York Times, 25 June, on line. 
Brenner, R. (1998), "Uneven Development and the Long Downturn: The Advanced Capitalist Economies from Boom to Stagnation, 1950-1998", New Left Review 229.

Brenner. R. (2002), The Boom and the Bubble, The U.S. in the World Economy, (London: Verso).

Brenner, R. (2004), "New Boom or New Bubble”, New Left Review 25.

Brewer, A. (1991), Marxist Theories of Imperialism: A Critical Survey, (London: Routledge).

Bronfenbrenner, K. and Luce, S. (2004), "The Changing Nature of Corporate Global Restructuring: The Impact of Production Shifts on Jobs in the U.S., China, and Around the Globe", Submitted to the U.S.-China Economic and Security Review Commission, 14 October, http://www.uscc.gov/researchpapers/2004/cornell_u_ mass_report.pdf.

Brown, C. (2004), “Trade Sector Leads Korea's Economic Growth in First Half of 2004", Korea Insight 6: 8.

Brown, P. and Lauder, H. (2001), Capitalism and Social Progress: The Future of Society in the Global Economy, (Basingstoke: Palgrave).

Burke, J. (2000), "U.S. Investment in China Worsens Trade Deficit", Briefing Paper 90, Economic Policy Institute, May, http://www.epinet.org/briefingpapers/FDI/ FDI_BP.pdf.

Burke, J.Epstein, G and Choi, M. (2004), "Rising Foreign Outsourcing and Employment Losses in U.S. Manufacturing, 1987-2002”, PERI Working Paper Series 89, Political Economy Research Institute, University of Massachusetts at Amherst, October.

Burkett, P. (1999), Marx and Nature, (New York: St. Martin's Press).

Burkett, P. and Hart-Landsberg, M. (1998), "East Asia and the Crisis of Development Theory", Journal of Contemporary Asia 28: 4.

Burkett, P. and Hart-Landsberg, M. (2000), Development, Crisis, and Class Struggle: Learning from Japan and East Asia, (New York: St. Martin's Press).

Burkett, P. and Hart-Landsberg, M. (2003), "A Critique of 'Catch-Up' Theories of Development”, Journal of Contemporary Asia 33: 2.

Business Korea. (2002), "Falling Exchange Rate and Profitability”, July.

Business Week. (2004), "Special Report, The China Price”, 6 December, on line.

Camdessus, M. (1997), "The Asian Crisis and the International Response", Speech delivered at the Institute of Advanced Business Studies (IESE), University of Navarra Barcelona, Spain, 28 November.

Cardoso, F. and Faletto, E. (1979), Dependency and Development in Latin America, (Berkeley: University of California Press).

Cathie, J. (1997/1998), "Financial Contagion in East Asia and the Origins of the Economic and Financial Crisis in Korea", Asia Pacific Business Review 4: 2/3.

Chang, D. (2002), "The Korean Labour Relations in Transition: Authoritarian Flexibility?", Labour, Capital and Society 35: 1.

Chang, H. and Yoo, C. (2002), "The Triumph of Rentiers? The 1997 Korean Crisis in a Historical Perspective", in Eatwell and Taylor (eds.). 
Chaudhry, K. (1993), "The Myths of the Market and the Common History of Late Developers", Politics \& Society 21: 2.

Cheng, A. (2004), "Rich-Poor Gap Among the Worst, Study Finds", South China Morning Post, 26 February, on line.

Cherry, J. (2005), “'Big Deal' or Big Disappointment? The Continuing Evolution of the South Korean Developmental State”, The Pacific Review 18: 3.

Chibber, V. (1999), "Building a Developmental State: The Korean Case Reconsidered", Politics \& Society 27: 3.

China Economic Net. (2004), "Implications of Wal-Mart's Procurement in China", 26 November, on line.

Cho, B. (2004), "The Nature of Financial Capital, the Financial System, and the Finance-led Accumulation Regime", Conference Paper, New Political Economy Group, 29-30 July.

Cho, H. (2002), "Living with Conflicting Subjectivities: Mother, Motherly Wife, and Sexy Woman in the Transition from Colonial-Modern to Postmodern Korea", in Kendal (ed.).

Cho, J. (1964), "Post-1945 Land Reforms and their Consequences in South Korea", Ph.D. Dissertation, Indiana University.

Cho, L., Kim, Y. and Shin, I. (eds.) (2002), Restructuring the Korean Financial Market in a Global Economy, (Seoul: Korea Development Institute).

Cho, Y. (1998), "Government Intervention, Rent Distribution, and Economic Development in Korea", in Aoki et al. (eds.).

Choi, G. (2003), "What Lies Ahead for the Korean Economy?”, Korea Herald, 27 January, on line.

Choi, J. (1989), Labor and the Authoritarian State, (Seoul: Korea University Press).

Chung, J. (1981), "La Théorie de La Baisse Tendencielle du Taux de Profit", (Louvain-la-Neuve: Institute des Sciences Economique, UCL).

Clarke, S. (1990), "The Marxist Theory of Overaccumulation and Crisis", Science and Society 54: 4.

Clarke, S. (1991a), Marx, Marginalism and Modern Sociology: From Adam Smith to Max Weber, (London: Macmillan).

Clarke, S. (1991b), "State, Class Struggle, and the Reproduction of Capital", in Clarke (ed.).

Clarke, S. (ed.) (1991), The State Debate, (Basingstoke: Macmillan).

Cleaver, H. (2002), "Work is Still Central Issue!”, in Dinerstein and Neary (eds.).

Coates, D. (2000), Models of Capitalism: Growth and Stagnation in the Modern Era, (Cambridge: Polity Press).

Cody, E. (2004), "Workers in China Shed Passivity, Spate of Walkouts Shakes Factories", Washington Post, 27 November, on line.

Conybeare, J. (2003), Merging Traffic: The Consolidation of the International Auto Industry, (Lanham: Rowman \& Littlefield).

Cooper, C. (2002), “Does China Pose an Economic Threat to Korea?", Korea Insight 4: 1 . 
Cooper, C. (2003), "Trade Winds Blow From West to East", in Korea Economic Institute (ed.).

Cowie, J. (1999), Capital Moves: RCA's Seventy-Year Quest for Cheap Labour, (NewYork: The New Press).

Coy, P. (2004), “Just How Cheap Is Chinese Labor?”, Business Week, 3 December, on line.

Crotty, J. (2002), The Effects of Increased Product Market Competition and Changes in Financial Markets on the Performance of Nonfinancial Corporations in the Neoliberal Era", PERI Working Paper Series 44.

Crotty, J. and Lee, K. (2001), "Economic Performance in Post-Crisis Korea: A Critical Perspective on Neoliberal Restructuring", PERI Working Paper Series 23, http://www.umass.edu/peri/pdfs/WP23.pdf.

Crotty, J. and Lee, K. (2002), "A Political-Economic Analysis of the Failure of Neoliberal Restructuring in Post-Crisis Korea”, Cambridge Journal of Economics 26.

Crotty, J. and Lee, K. (2004), “Was the IMF's Imposition of Economic Regime Change in Korea Justified? A Critique of the IMF's Economic and Political Role Before and After the Crisis", PERI Working Paper Series 77.

Crotty, J. and Lee, K. (2005), "The Effects of Neoliberal 'Reforms' on the PostCrisis Korean Economy”, PERI Working Paper Series 111.

Cumings, B. (1981), The Origins of the Korean War, Liberation and the Emergence of Separate Regimes, Vol. 1, (Princeton: Princeton University Press).

Cumings, B. (1984), "The Origins of the Development of the Northeast Asian Political Economy: Industrial Sectors, Product Cycles, and Political Consequences", International Organization 38: 1.

Cumings, B. (1999), "The Asian Crisis, Democracy, and the End of 'Late' Development", in Pempel (ed.).

Dasgupta, B. (1998), Structural Adjustment, Global Trade and the New Political Economy of Development, (London: Zed Books).

Davis, D. (2004), Discipline and Development: Middle Classes and Prosperity in East Asia and Latin America, (Cambridge: Cambridge University Press).

Davis, M. (2004), "Planet of Slums", New Left Review 26.

de Brunhoff, S. (2003), "Financial and Industrial Capital: A New Class Coalition", in Saad-Filho (ed.).

De Rivero, O. (2001), The Myth of Development: Non-viable Economies of the $21^{\text {st }}$ Century, (London: Zed Books).

Deininger, K. (2003), Land Policies for Growth and Poverty Reduction, (Washington D.C.: The World Bank and Oxford University Press).

Deyo, F. (1987), The Political Economy of the New Asian Industrialism, (Ithaca: Cornell University Press).

Deyo, F. (1996), "Introduction: Social Reconstructions of the World Automobile Industry", in Deyo (ed.).

Deyo, F. (ed.) (1996), Social Reconstructions of the World Automobile Industry, (London: Macmillan). 
Daimond, L. and Shin, D. (eds.) (1999), Institutional Reform and Democratic Consolidation in Korea, (Stanford, CA: Hoover Institution Press).

Dicken, P. (1998), Global Shift: Transforming the World Economy, (London: The Guilford Press).

Dierckxsens, W. (2000), The Limits to Capitalism: An Approach to Globalization without Neoliberalism, (London: Zed Books).

Dinerstein, A. and Neary, M. (eds.) (2002) The Labour Debate: An Investigation into the Theory and Reality of Capitalist Work, (Aldershot: Ashgate).

Dirlik, A. (1997), The Postcolonial Aura: Third World Criticism in the Age of Global Capitalism, (Boulder, CO: Westview Press).

Domhoff, G. (2005), Who Rules America? Power, Politics, and Social Change, (New York: McGraw-Hill).

Duménil, G. (1980), De la Valeur aux Prix de Production, (Paris: Economica).

Duménil, G. (1984), “The So-Called 'Transformation Problem’ Revisited: A Brief Comment", Journal of Economic Theory 33.

Duménil, G. and Lévy, D. (1993), The Economics of the Profit Rate, (Aldershot: Edward Elgar).

Duménil, G. and Lévy, D. (2002), “The Profit Rate: Where and How Much Did It Fall? Did It Recover? USA 1948-2000”, Review of Radical Political Economics 34: 4.

Duménil, G. and Lévy, D. (2004), “The Real and Financial Components of Profitability (United States, 1952-2000)", Review of Radical Political Economics 36: 1 .

Durand, C. (1990), "The Exhaustion of Developmental Socialism: Lessons from China", Monthly Review 42: 7.

Eatwell, J. and Taylor, L. (eds.) (2002), International Capital Markets, (Oxford: Oxford University Press).

Economic Intelligence Unit. (2002), "Drastic plastic? The Credit Card Boom", 3 June, on line.

Economist. (2003a), "A Survey of Asian Finance”, 8 February.

Economist. (2003b), "A Survey of South Korea", 19 April.

Economist. (2004), "The Dragon and the Eagle", 2 October.

Economist. (2005a), "The Struggle of Champions", 6 January.

Economist. (2005b), "Special Report: Samsung Electronics", 15 January.

Economist. (2005c), "Rebuilding Failed States: From Chaos to Order", 5 March.

Economist. (2005d), "The Cauldron Boils", 29 September, on line.

Editorial. (2005a), "Sluggish Income Growth", Korea Herald, 21 May.

Editorial. (2005b), "Economy at the Crossroads", Korea Herald, 2 June, on line.

Elson, D. (1979), "The Value Theory of Labour", in Elson (ed.).

Elson, D. (ed.) (1979), Value: The Representation of Labour in Capitalism, (London: CSE Books).

Escobar, A. (1995), Encountering Development: The Making and Unmaking of the Third World, (Princeton, NJ: Princeton University Press).

Evans, P. (1995), Embedded Autonomy: States and Industrial Transformation, 
(Princeton: Princeton University Press).

Far Eastern Economic Review. (2003), "China Breaks with its Wartime Past", 7 August.

Fernald, J. and Loungani, P. (2004), "Comrades or Competitors? On Trade Relationships Between China and Emerging Asia", Chicago Fed Letter 20.

Ferri, G. and Kang. T. (1999), "The Credit Channel at Work: Lessons from the Financial Crisis in Korea", Economic Notes 28: 2.

Fine, B., Lapavitsas, C. and Saad-Filho, A. (2004), "Transforming the Transformation Problem: Why the 'New Interpretation' Is a Wrong Turning”, Review of Radical Political Economics 36: 1.

Foley, D. (1982), "The Value of Money, the Value of Labor Power, and the Marxian Transformation Problem", Review of Radical Political Economics 14: 2.

Foley, D. (2005), "Marx's Theory of Money in Historical Perspective", in Moseley (ed.).

Forsberg, A. (2000), America and the Japanese Miracle: The Cold War Context of Japan's Postwar Economic Revival, 1950-1960, (Chapel Hill, NC: University of North Carolina Press).

Freeman, A. (2004), "The Case for Simplicity: a Paradigm for the Political Economy of the $21^{\text {st }}$ Century", in Freeman et al. (eds.).

Freeman, A., Kliman, A. and Wells, J. (eds.), (2004), The New Value Controversy and the Foundations of Economics, (Cheltenham: Edward Elgar).

Fukuyama, F. (1999), "Asian Values, Korean Values, and Democratic Consolidation”, in Daimond and Shin (eds.).

Galor, O., Moav, O. and Vollrath, D. (2003), "Land Inequality and the Origin of Divergence and Overtaking in the Growth Process: Theory and Evidence", Working Paper, Hebrew University, Dept. of Economics.

Galor, O., Moav, O. Vollrath, D. (2005), "Land Inequality and the Emergence of Human Capital Promoting Institutions", Economics Working Papers 2005-03, Brown University.

Gerschenkron, A. (1962), Economic Backwardness in Historical Perspective, (Cambridge: Belknap Press).

Giddens, A. and Held, D. (eds.) (1983), Classes, Power and Conflict, (Basingstoke: Macmillan).

Gilboy, G. (2004), “The Myth Behind China's Miracle”, Foreign Affairs, JulyAugust, on line.

Gough, N. (2005), "Trouble on the Line", Time Asia, 31 January, on line.

Gouverneur, J. (1990), "Productive Labor, Price/Value Ratio and Rate of Surplus Value: Theoretical Viewpoints and Empirical Evidence", Cambridge Journal of Economics 14: 1 .

Gouverneur, J. (2004), Understanding the Economy, on line.

Greider, W. (1997), One World Ready or Not: The Manic Logic of Global Capitalism, (New York: Touchstone).

Griffin, K. and Gurley, J. (1985), "Radical Analyses of Imperialism, The Third World, and the Transition to Socialism: A Survey Article", Journal of Economic 
Literature 23.

Griffin, K. and Khan, A. (2000), "Poverty and the Distribution of Land", Working Paper, 00-09, Department of Economics, University of California, Riverside.

Grilli, E. (2002), "The Asian Crisis: Trade Causes and Consequences," The World Economy 25: 2.

Gruenwald, P. (2003), "Korea and the IMF”, in Korea Economic Institute (ed.).

Haggard, S. (1990), Pathways from the Periphery, (Ithaca: Cambridge University Press).

Halevi, J. (1984), "Structure Economique et Demande Effective", Economie Appliquee, 37: 1.

Halevi, J. (1999), "The Accumulation Process in Japan and East Asia as Compared with the Role of Germany in European Post-war Growth", in Bellofiore (ed.).

Halevi, J. and Fontaine, J. (eds.) (1998), Restoring Demand in the World Economy: Trade, Finance and Technology, (Aldershot: Edward Elgar).

Halevi, J. and Kriesler, P. (1998), "History, Politics, and Effective Demand in Asia", in Halevi and Fontaine (eds.).

Hardt, M. and Negri, A. (2000), Empire, (Cambridge: Harvard University Press).

Hardt, M. and Negri, A. (2004), Multitude, (New York: Penguin).

Hart-Landsberg, M. (1993), The Rush To Development: Economic Change and Political Struggle in South Korea, (New York: Monthly Review Press).

Hart-Landsberg, M. (2004a), "International Conditions and South Korean Capital Accumulation, 1987-2003", Conference Paper, Institute for Social Sciences of Gyeongsang National University, 22 May.

Hart-Landsberg, M. (2004b), "The South Korean Economy and U.S. Policy”, Asian Perspective 28: 4.

Hart-Landsberg, M. (2005), "South Korea: The State of Political Struggle", Monthly Review Webzine, 15 September, http://mrzine.monthlyreview.org/ hartlandsberg 150905.html.

Hart-Landsberg, M. and Burkett, P. (1998), “Contradictions of Capitalist Industrialization in East Asia: A Critique of 'Flying Geese' Theories of Development", Economic Geography 74: 2.

Hart-Landsberg, M and Burkett, P. (2001), "Economic Crisis and Restructuring in South Korea: Beyond the Free Market-Statist Debate", Critical Asian Studies 33: 3.

Hart-Landsberg, M. and Burkett, P. (2005a), China and Socialism: Market Reforms and Class Struggle, (New York: Monthly Review Press).

Hart-Landsberg, M. and Burkett, P. (2005b), "China and Socialism: Engaging the Issues", Critical Asian Studies 37: 4.

Harvey, D. (2003), The New Imperialism, (Oxford: Oxford University Press).

Harvey, D. (2006), Spaces of Global Capitalism: A Theory of Uneven Geographical Development, (London: Verso).

Hatch, W. and Yamamura, K. (1996), Asia in Japan's Embrace: Building A Regional Production Alliance, (Cambridge: Cambridge University Press).

Hayami, Y., Ruttan, V. and Southworth, H. (eds.) (1979), Agricultural Growth in 
Japan, Taiwan, Korea, and Philippines, (Honolulu: The University Press of Hawaii).

Healey, D. (1991), Japanese Capital Exports and Asian Economic Development, (Paris: OECD).

Holland, T. (2004), "Labor Pains", Far Eastern Economic Review 23, September.

Holliday, I. and Wilding, P. (2003), Welfare Capitalism in East Asia: Social Policy in the Tiger Economies, (Basingstoke: Palgrave).

Holloway, J. (1996), "The Abyss Open: The Rise and Fall of Keynesianism", in Bonefeld and Holloway (eds.).

Holst, D. and Weiss, J. (2004), "ASEAN and China: Export Rivals or Partners in Regional Growth?", World Economy 27: 8.

Hong Kong Confederation of Trade Unions. (2004), Chinese Labor and the WTO, http://www.ihlo.org/.

Hong, Y. (2002), "Unity Between Formal and Informal Workers at E-Land, Korea", Asian Labour Update, http://www.amrc.org.hk/alu/Alu40/014004.htm, Hong Kong: Asia Monitor Resource Centre.

Hoogvelt, A. (1997), Globalization and the Postcolonial World: The New Political Economy of Development, (Baltimore, MD: The Johns Hopkins University Press).

International Monetary Fund. (1997), "Aim of Korea Program is to Stanch Immediate Crisis, Permit Return to Stability and Growth", IMF Survey 26: 3, 15 December. Jang, S. (2004), Continuing Suicide Among Laborers in Korea", Labor History 45: 3.

Jeon, Y. and Kim, Y. (2000), "Land Reform, Income Redistribution, and Agricultural Production in Korea", Economic Development and Cultural Change 48: 2.

Jeong, S. (1997), "The Social Structure of Accumulation in South Korea: Upgrading or Crumbling?", Review of Radical Political Economics 29: 4.

Jeong, S. (2004), "Trend of Capital Accumulation in Korea after the 1997 Crisis: A Marxian Analysis", Paper presented for The $4^{\text {th }}$ International Marx Congress, Paris, 1 October.

Jeong, S. (2005), “Trend of Marxian Ratios in Korea: 1970-2003", Conference Paper, Institute for Social Sciences, Gyeongsang National University, 20 May.

Jeong, S. and Shin, J. (1999), "Debates on the Economic Crisis within the Korean Left", Rethinking Marxism 11: 2.

Johnson, C. (1982), MITI and the Japanese Miracle: the Growth of Industrial Policy, 1925-1975, (Stanford, CA: Stanford University Press).

Johnson, C. (1987), "Political Institutions and Economic Performance: The Government-Business Relationship in Japan, South Korea and Taiwan", in Deyo (ed.).

Johnson, C. (1996), Japan: Who Governs? The Rise of the Developmental State, (New York: W. W. Norton).

Kaldor, N, (1989), Further Essays on Economic Theory and Policy, (New York: Holmes \& Meier).

Kalecki, M. (1943), "Political Aspects of Full Employment", in Kalecki (1990). 
Kalecki, M. (1944), “Three Ways to Full Employment”, in Kalecki (1990).

Kalecki, M. (1945), “Full Employment by Stimulating Private Investment?”, in Kalecki (1990).

Kalecki, M. (1976), Essays in Developing Economies, (Hassocks: Harvester Press).

Kalecki, M. (1990), Collected Works of Michal Kalecki. Volume 1. Capitalism: Business Cycles and Full Employment, edited by J. Osiatynski and translated by C. Kisiel, (Oxford: Oxford University Press).

Kang, C. (2000), "Segyehwa Reform of the South Korean Developmental State", in Kim (ed.).

Kato, T. (1984), "A Preliminary Note on the State in Contemporary Japan", Hitotsubashi Journal of Social Studies 16: 1.

Keliher, M. (2004), "Replacing U.S. in Asian Export Market", Asia Times, 11 February, on line.

Kendal, L. (ed.) (2002), Under Construction: The Gendering of Modernity, Class, and Consumption in the Republic of Korea, (Honolulu: University of Hawaii Press).

Kentor, J. (2005), "The Growth of Transnational Corporate Networks: 1962-1998”, Journal of World-Systems Research 11: 2.

Kester, C. (1996), “American and Japanese Corporate Governance: Convergence to Best Practice", in Berger and Dore (eds.).

Keynes, J. (1936), The General Theory of Employment, Interest and Money: The Collected Writings of John Maynard Keynes: Volume VII, (London: The Macmillan Press, 1973).

Kiely, R. (1995), Sociology and Development: The Impasse and Beyond, (London: UCL Press).

Kim, E.-M. (1997), Big Business Strong State: Collusion and Conflict in South Korean Development, 1960-1990, (Albany: State University of New York Press).

Kim, H. (2003), “Chaebol Lobby Warns of Exodus”, Korea Herald, 27 June, on line.

Kim, H. (2004), "China Outstrips Korean Car Production”, Korea Herald, 2 February, on line.

Kim, Ji-ho. (2004a), "Morgan Stanley Warns of Economic Slowdown in China", Korea Herald, 24 March, on line.

Kim, Ji-ho. (2004b), “Chaebol Investment Falls 33.5\%”, Korea Herald, 12 July, on line.

Kim, Ji-hyun. (2004a), "Labor Unrest Slashes Output, Exports”, Korea Herald, 17 February, on line.

Kim, Ji-hyun. (2004b), "Flexibility in Labor Top Priority”, Korea Herald, 22 May, on line.

Kim, J.-K. (2004), "Hardship More Serious than 6 Years Ago", Korea Times, 26 May, on line.

Kim, J.-K. (2005), "South Korea's Consumption Growth Lowest in OECD”, Korea Times, 3 January, on line.

Kim, Jung-min. (2005), "Economy Expanded Slowest in Two Years during First 
Quarter", Korea Herald, 21 May.

Kim, Mi-hui. (2003), "Factories Relocating Abroad to Cut Costs", Korea Herald, 25 October, on line.

Kim, S. (ed.) (2000), Korea's Globalization, Cambridge, (Cambridge: Cambridge University Press).

Kim, S.-H. and Cho, B. (1999), "The South Korean Economic Crisis: Contrasting Interpretations and an Alternative For Economic Reform", Studies in Political Economy 60.

Kim So-young. (2005a), "Manufacturing, Construction, Retail Sectors Lost Jobs", Korea Herald, 19 May.

Kim So-young. (2005b), "Foreign Investors Increase Stakes to Gain More Input", Korea Herald, 20 June, on line.

Kim Sung-mi. (2003), "Labor Conflict May Hit 13-Year Peak”, Korea Herald, 13 November, on line.

Kim, Y. (2005), "DJnomics and the Transformation of the Developmental State", Journal of Contemporary Asia 35: 4.

Kirk, D. (1999), Korean Crisis: Unraveling of the Miracle in the IMF Era, (Basingstoke: Palgrave).

Kirk, D. (2003), “Contract at Hyundai Raises Sights of Korean Workers”, New York Times, 19 August.

Kitschelt, H., Lange, P., Marks, G. and Stephens, J. (eds.) (1999), Continuity and Change in Contemporary Capitalism, (Cambridge: Cambridge University Press).

Kleinknecht, A., Mandel, E. and Wallerstein, I. (eds.) (1992), New Findings in LongWave Research, (New York: St.Martin's Press).

Koo, H. (1993), "The State, Minjung, and the Working Class in South Korea", in Koo (ed.).

Koo, H. (2001), Korean Workers: The Culture and Politics of Class Formation, (Ithaca: Cambridge University Press).

Koo, H. (ed.) (1993), State and Society in Contemporary Korea, (Ithaca: Cornell University Press).

Koo, B. (2002), "Corporate Restructuring and Financial Reform in Korea", in Cho et al. (eds.).

Korea Development Bank. (2006), http://www.kdb.co.kr/, 16 February.

Korea Economic Institute. (ed.) (2003), Korea 's Economy 2003, (Washington, D.C.: Korea Economic Institute).

Korea Herald. (2003a), "Labor Group Seeks Equality for All Workers”, 16 January, on line.

Korea Herald. (2003b), “Korea’s State Debt Tripled Over 5 Years”, 8 September, on line.

Korea Herald. (2005), "Economy at the Crossroads", 2 June, on line.

Korea Insight, Korea Economic Institute, http://www.keia.org/2-1-insight.html.

Korean Confederation of Trade Unions (KCTU). (1997), The KCTU Proposal for an Agreement to Overcome the Economic Crisis, http://www.kctu.org/arguments/ 
sp004.htm.

Korten, D. (1995), When Corporations Rule the World, (West Hartford, Connecticut: Kumarian Press).

Kosai, Y. (1986), The Era of High-Speed Growth: Notes on the Postwar Japanese Economy, translated by J. Kaminski, (Tokyo: University of Tokyo Press).

Kourkoulakos, S. (2003), "The Specificity of Dialectical Reason", in Albritton and Simoulidis (eds.).

Kriesler, P. and Nevile, J. (2003), "Macroeconomic Constraints with Globalization”, in Bloch (ed.).

Kriesler, P. and Halevi, J. (1996), "Asia, Japan and the Internationalization of Effective Demand", Economies et Societes, Monnaie et Production, Series M.P 10.

Kristof, N. and Sanger, D. (1999), "How U.S. Wooed Asia to Let Cash Flow In", The New York Times, 16 February, on line.

Kurth, J. (1979), "The Political Consequences of the Product Cycle: Industrial History and Political Outcomes", International Organization 33: 1.

Kusnets, P. (1982), "The Dramatic Reversal of 1979/1980: Contemporary Economic Development in Korea", Journal of Northeast Asian Studies 1: 3.

Labour News. (2004), 23 February.

Laibman, D. (1999), "Productive and Unproductive Labor: A Comment", Review of Radical Political Economics 31: 2.

Lall, S. and Albaladejo, M. (2004), "China's Competitive Performance: A Threat to East Asian Manufactured Exports?”, World Development 32: 9.

Law, C. (1991), "Motor Vehicle Manufacturing: the Representative Industry", in Law (ed.).

Law, C. ed. (1991), Restructuring the Global Automobile Industry, (London: Routledge).

Lee, C.-H., Lee, K. and Lee, K.-K. (2002). "Chaebols, Financial Liberalization and Economic Crisis: Transformation of Quasi-Internal Organization in Korea”, Asian Economic Journal 16: 1.

Lee, C.-K. (2004), "'Made in China': Labor as a Political Force?”, Presentation at the 2004 Mansfield Conference, The University of Montana, Missoula, 18-20 April, http://www.umt.edu/mansfield/Ching\%20Kwan\%20Lee\%20paper.pdf.

Lee, J.-W. (1998), "Economic Growth and Human Development in the Republic of Korea, 1945-1992”, Occasional Paper, 24, United Nations Development Program.

Lenin, V. (1916), “Notebook on Imperialism”, Collected Works, Vol.39, (Moscow: Progress Publisher).

Lim, H. (1985), Dependent Development in Korea 1963-1979, (Seoul: Seoul National University Press).

Linder, S. (1986), The Pacific Century: Economic and Political Consequences of Asian-Pacific Dynamism, (Stanford, CA: Stanford University Press).

Lipietz, A. (1982), "The So-Called Transformation Problem Revisited”, Journal of Economic Theory 26: 1. 
Lipietz, A. (1985), The Enchanted World: Inflation, Credit and the Global Crises, (London: Verso).

Lipietz, A. (1987), Mirages and Miracles, (London: Verso).

Lister, J. (2003), “Korea's Economy in Recession: Is it Technical?", Korea Insight 5: 9.

Lister, J. (2004), “Outlook for Korea's Economy”, Korea Insight 6: 1.

Lo, D. (1999), "The East Asian Phenomenon: The Consensus, the Dissent, and the Significance of the Present Crisis", Capital and Class 67.

Lowe-Lee, F. (2004a), "A New Financial Crisis: Credit Card Excesses", Korea Insight 6: 2 .

Lowe-Lee, F. (2004b), "Economic Trends: Foreigners Weary About Free Economic Zones", Korea Insight 6: 6.

Lowe-Lee, F. (2005), "Economic Trends: Growing Presence of Foreign Capital Worries Domestic Financial Institutions", Korea Insight 7: 4.

Lowe-Lee, F. (2006), "Economic Update: Income Gap Widens”, Korea Insight 8: 3.

Mage, S. (1963), "The Law of the Falling Tendency of the Rate of Profit", Ph.D. Dissertation, Columbia University.

Manyin, M. (2004), "South Korea-U.S. Economic Relations: Cooperation, Friction, and Future Prospects", CRS Report for Congress, updated 1 July, Library of Congress, Washington D.C.

Marglin, S. (1983), "What Do the Bosses Do? The Origins and Functions of Hierarchy in Capitalist Production", in Giddens and Held (eds.).

Martin, J. and Torres, R. (2001), "Korean Labor Market and Social Safety-net Reforms: Challenges and Policy Requirements", Paper presented at the Forum on Labor Market Reforms in Korea, Korea Labor Institute, Seoul, February.

Marx, K. (1971), A Contribution to the Critique of Political Economy, (London: Lawrence and Wishart).

Marx, K. (1976), Capital, Vol.1, (New York: Penguin).

Marx, K. (1978), “The Value-Form”, Capital and Class 4.

Marx, K. (1981), Capital, Vol.3, (New York: Penguin).

Marx, Karl. (1987), “Zur Kritik der Politischen Oekonomie”, Karl Marx-Frederick Engels, Collected Works, Volume 29, (New York: International Publishers).

Mason, S. and Council on East Asian Studies (1980), The Economic and Social Modernization of the Republic of Korea, (Cambridge: Harvard University Press).

McGregor, R. (2004), “Competition in China Keeps Foreign Profits Low”, Financial Times, 5 December, on line.

McGuckin, R. and Spiegelman, M. (2004), “China's Experience with Productivity and Jobs: Benefits and Costs of Change", Parts I, II, III, IV, Research Report R-1352-04-RR, The Conference Board, June, http://www.conference-board.org/ publications/reports.cfm.

Mitchell, C. (1949), "Land Management and Tenancy Reform in Korea under the U.S. Army Occupation”, Ph.D. Dissertation, Harvard University. 
Mitchell, C. (1952), "Land Reform in Asia: a Case Prepared for the NPAAgriculture Committee on National Policy", National Planning Association.

Mohun, S. (1998), "Unproductive Labor and the Rate of Profit in Australia 1966/671991/92", in Bellofiore (ed.).

Mohun, S. (2002), "Productive and Unproductive Labor: A Reply to Houston and Laibman", Review of Radical Political Economics 34: 2.

Mohun, S. (2003), "Does All Labour Create Value?”, in Saad-Filho (ed.).

Mohun, S. (2004a), “The Australian Rate of Profit 1965-2001”, Journal of Australian Political Economy 52.

Mohun, S. (2004b), "On Measuring the Wealth of Nations: the U.S. Economy, 19642001", Mimeo.

Mohun, S. (2004c), "Distributive Shares in the U.S. Economy, 1964-2001", Mimeo.

Mohun, S. (2004d), “Theory and Measurement: How Do Recent Developments in Value Theory Help?", Paper presented for The $4^{\text {th }}$ International Marx Congress, Paris, 1 October.

Moon, I. (1997), "Seoul is Still Teetering on the Edge", Business Week, 29 December.

Moseley, F. (1991), The Falling Rate of Profit in the Postwar United States Economy, (New York: St.Martin's Press).

Moseley, F. (1997), “The Rate of Profit and the Future of Capitalism”, Review of Radical Political Economics 29: 4.

Moseley, F. (1999), "The Decline of the Rate of Profit in the Post-war United States Economy: Due to Increased Competition or Increased Unproductive Labour", Historical Materialism 4.

Moseley, F. (2004), "Marxian Crisis Theory and the Postwar U.S. Economy", Conference Paper, Institute for Social Sciences, Gyeongsang National University, 22 May.

Moseley, F. (ed.) (2005), Marx's Theory of Money, (New York: Palgrave Macmillan).

Nakajima, A. and Izumi, H. (1995), "Economic Development and Unequal Exchange among Nations: Analysis of the USA, Japan and South Korea", Review of Radical Political Economics 27: 3.

Nakamura, T. (1983), Economic Growth in Prewar Japan, translated by R. Feldman, (New Haven: Yale University Press).

Nam, S. and Yang, J. (2003), "Potential Impact of Changes in Consumer Preferences on Trade in the Korean and World Motor Vehicle Industry", Korea Institute for International Economic Policy, Working Paper, 03-08.

Naughton, B. (1996), “China's Emergence and Prospects as a Trading Nation”, Brookings Papers on Economic Activity 2.

Navarro, V. (1992), "Has Socialism Failed? An Analysis of Health Indicators under Socialism”, International Journal of Health Services 22: 4.

Neary, M. (2002), "Labour Moves: A Critique of the Concept of Social Movement Unionism", in Dinerstein and Neary (eds.). 
Negri, A. (1994), Labor of Dionysus, (Minneapolis: University of Minnesota Press).

New York Times. (2005), "South Korea Becoming a Big Asian Investor", 20 October.

New York Times. (2006), “China’s Youth Look to Seoul for Inspiration”, 2 January.

Ochoa, E. (1984), "Labor-Values and Prices of Production: an Interindustry Study of the U.S. Economy, 1947-1972”, Ph.D. Dissertation, New School for Social Research.

OECD. (2004), OECD Economic Surveys: Korea, (Paris: OECD).

Olsen, G. (1974), U. S. Foreign Policy and the Third World Peasant: Land Reform in Asia and Latin America, (Westport: Praeger Publishers).

Overbeek, H. (2000), "Transnational Historical Materialism: Theories of Transnational Class Formation and World Order", in Palan (ed.).

Pak, K. (1956), "Economic Analysis of Land Reform in the Republic of Korea, 1954-55", Ph.D. Dissertation, University of Illinois.

Palan, R. (ed.) (2000), Global Political Economy: Contemporary Theories, (London: Routledge).

Panitch, L. and Leys, C. (eds.) (1999), Global Capitalism versus Democracy: Socialist Register, (London: Merlin Press).

Park, S. (1995), "Land Reform in Korea: A Reappraisal of Previous Research and A Proposal for A New Research Strategy," Humane Studies, Humane Studies Institute of Yeungnam University.

Pasinetti, L. (1973), "The Notion of Vertical Integration in Economic Analysis", Metroeconomica 25.

Pasinetti, L. (1981), Structural Change and Economic Growth: A Theoretical Essay on the Dynamics of the Wealth of Nations, (Cambridge: Cambridge University Press).

Pempel, T. (ed.) (1999), The Politics of the Asian Economic Crisis, (Ithaca: Cornell University Press).

People's Daily. (2004), "Income Gaps Have to be Closed”, 25 February, on line.

People's Daily. (2005), “China's Middle Class Defined by Income”, 20 January, on line.

Pirie, I. (2005), “The New Korean State”, New Political Economy 10: 1.

Postone, M. (1996), Time, Labor and Social Domination, (Cambridge: Cambridge University Press).

Prosterman, R. and Hanstad, T. (2000), "Land Reform: A revised Agenda for the 21st Century", RDI report on Foreign Aid and Development 108, Rural Development Institute.

Putzel, J. (1992), A Captive Land: The politics of Agrarian Reform in the Philippines, (New York: Monthly Review Press).

Randal, V. and Theobald, R. (1998), Political Change and Underdevelopment, (Durham: Duke University Press).

Rieu, D. (2005), "Estimating the Sectoral Rates of Surplus Value: Methodological Issues", in this volume. 
Rieu, D. (2006), "A Reexamination of the Quantitative Issues in the "New Interpretation", Review of Radical Political Economics 38: 2.

Roach, S. (2005), "What if China's Slows?", Global Economic Forum, Morgan Stanley, 23 May, on line.

Robison, R., Beeson, M., Jayasuriya, K. and Kim, H-R. (eds.) (2000), Politics and Markets in the Wake of the Asian Crisis, (London: Routledge).

Roemer, J. (1978), "Differentially Exploited Labor: A Marxian Theory of Discrimination", Review of Radical Political Economics 10: 2.

Rubin, I. (1990), Essays on Marx's Theory of Value, (New York: Black Rose Books).

Saad-Filho, A. ed. (2003), Anti-Capitalism: A Marxist Introduction, (London: Pluto Press).

Sachs, J. (1997), “IMF is a Power unto Itself”, Financial Times, 11 December.

Sakurai, H. (1983), "Why Did the Korean War 'Break Out' on June 25, 1950? A Summary of a New Hypothesis", Mimeo.

Savran, S. and Tonak, E. (1999), "Productive and Unproductive Labour: An Attempt at Clarification and Classification", Capital and Class 68.

Schaller, M. (1985), The American Occupation of Japan: The Origins of the Cold War in Asia, (New York: Oxford University Press).

Sekine, T. (1997), An Outline of the Dialectic of Capital, 2 Vols., (London: Macmillan Press).

Shaikh, A. (1992), "The Falling Rate of Profit as the Cause of Long Waves: Theory and Empirical Evidence", in Kleinknecht et al. (eds.).

Shaikh, A. (1999), "Explaining the Global Economic Crisis", Historical Materialism 5.

Shaikh, A. and Tonak, E. (1994), Measuring the Wealth of Nations, (Cambridge: Cambridge University Press).

Shin C.-S. (2005), "Capital Stock Matrix for the Korean Economy: 1995-2000”, Seoul Journal of Economics 18: 1.

Shin, G. (1998), “Agrarian Conflict and the Origins of Korean Capitalism”, American Journal of Sociology 103.

Shin, J. and Chang, H. (2005), "Economic Reform after the Financial Crisis: a Critical Assessment of Institutional Transition and Transition Costs in South Korea", Review of International Political Economy 12: 3.

Sim, S. (2003), "Income Gap Widened Sharply", Korea Herald, 17 February.

Simmons, B. (1999), "The Internationalization of Capital”, in Kitschelt et al. (eds.).

Smith, M. (1991), "Respecifying Marx's Value Categories: A Theoretical and Empirical Reconsideration of the 'Law of the Falling Rate of Profit'", Studies in Political Economy 35.

Smith, M. and Taylor, K. (1996), "Profitability Crisis and the Erosion of Popular Prosperity: The Canadian Economy, 1947-1991”, Studies in Political Economy 49.

Soh, J. (2003), “Gap Between Rich, Poor in Urban Areas Widens”, Korea Times, 7 January, on line. 
Song, B. (1990), The Rise of the Korean Economy, (New York: Oxford University Press).

Stangarone, T. (2006), "Investment Down, but More Free Trade in Korea's Future”, Korea Insight 8: 2.

Steinfeld, E. (2004), “China's Shallow Integration: Networked Production and the New Challenges for Late Industrialization”, World Development 32: 11.

Stiglitz, J. (2001), "From Miracle to Crisis to Recovery: Lessons from Four Decades of the East Asian Experience", in Stiglitz. and Yusuf (eds.).

Stiglitz, J. and Yusuf, S. (eds.) (2001), Rethinking the East Asian Miracle, (Oxford: Oxford University Press).

Sylos-Labini, P. (1969), Oligopoly and Technical Progress, translated from the Italian by E. Henderson, (Cambridge: Harvard University Press).

Tang, K. (2000), Social Welfare Development in East Asia, (Basingstoke: Palgrave).

Tham, S. (2001), "Can Malaysian Manufacturing Compete with China in the WTO?", Asia-Pacific Development Journal 8: 2.

Thelen, K. and Kume, I. (1999), "The Effects of Globalization on Labor Revisited: Lessons from Germany and Japan”, Politics and Society 27: 4.

U.S. Department of Commerce. (2005), "U.S. Aggregate Foreign Trade Data", http://www.ita.doc.gov/td/industry/otea/usfth/tabcon.html.

UNCTAD. (2002a), Trade and Development Report 2002, (New York: United Nations).

UNCTAD. (2002b), World Investment Report 2002: Transnational Corporations and Export Competitiveness, (New York: United Nations).

UNCTAD. (2005), Trade and Development Report 2005, (New York: United Nations).

Uno, K. (1980), Principles of Political Economy: Theory of a Purely Capitalist Society, (Brighton: The Harvester Press Ltd).

Wade, R. (1990), Governing the Market: Economic Theory and the Role of Government in East Asian Industrialism, (Princeton: Princeton University Press).

Wade, R. (1992), "East Asia's Economic Success: Conflicting Perspectives, Partial Insights, Shaky Evidence", World Politics 44.

Wade, R. and Veneroso, F. (1998), "The Asian Crisis: the High Debt Model vs. the Wall Street-Treasury-IMF Complex", New Left Review 228.

Warren, B. (1980), Imperialism, Pioneer of Capitalism, (London: NLB).

Watanabe, T. (1992), Asia: Its Growth and Agony, (Hawaii: University of Hawaii Press).

Westra, R. (1996), "Periodizing Capitalism and the Political Economy of Post-War Japan", Journal of Contemporary Asia 26: 4.

Westra, R. (2001), "Phases of Capitalism and Post-Capitalist Social Change", in Albritton et al. (eds.).

Westra, R. (2002), "Marxian Economic Theory and an Ontology of Socialism: A Japanese Intervention", Capital and Class 78. 
Westra, R. (2003a), "Social Theory, Economic Crisis, and the Japanese Political Economy: a Review Article", Review of International Political Economy 10: 2.

Westra, R. (2003b), “Globalization: The Retreat of Capital to the 'Interstices' of the World?", in Westra and Zuege (eds.).

Westra, R. (2004a), “The 'Impasse' Debate and Socialist Development”, in Albritton et al. (eds.).

Westra, R. (2004b), "Globalization and the Pathway to Socio-Material Betterment", Review of Radical Political Economics 36: 3.

Westra, R. (2006), "The Capitalist Stage of Consumerism and South Korean Development", Journal of Contemporary Asia 36: 1.

Westra, R and Zuege, A. (eds.) (2003), Value and the World Economy Today: Production, Finance, and Globalization, (Basingstoke: Palgrave).

Whang, I, (1982), “Administration of Land Reform in Korea”, Working Paper 8301, Korea Development Institute.

Wolff, E. (1987), Growth, Accumulation, and Unproductive Activity, (Cambridge: Cambridge University Press).

Wolff, E. (2003), "What's Behind the Rise in Profitability in the US in the 1980s and 1990s", Cambridge Journal of Economics 27: 4.

Woo-Cumings, M. (1991), Race to the Swift: State and Finance in Korean Industrialization, (New York: Columbia University Press).

Woo-Cumings, M. (1998), "The Political Economy of Growth in East Asia: A Perspective on the State, Market, and Ideology", in Aoki et al. (eds.).

Woo-Cumings, M. (2001), "Miracle as Prologue: The State and the Reform of the Corporate Sector in Korea", in Stiglitz and Yusuf (eds.).

Woo-Cumings, M. (ed.) (1999), The Developmental State, (Ithaca: Cambridge University Press).

World Bank. (1993), The East Asian Miracle: Economic Growth and Public Policy, (Oxford: Oxford University Press).

World Watch Institute. (2004), State of the World, (New York: Norton).

Yoo, S. (2005), "EUCCK Gets Frank to Lure Foreign Investment”, Korea Herald, 7 April, on line.

\section{Works in Korean}

Academy of Korean Studies (ed.) (1999a), Korean Industrialization and Economic Structure in 1960s, (Seoul: Baeksanseodang).

Academy of Korean Studies (ed.) (1999b), Political and Social Changes in 1960s, (Seoul: Baeksanseodang).

Ahn, B. (1989), "Korean Economy as a Medium Developed Capitalism", Movement for Thoughts and Literature 2.

Ahn, J.-Y., Cho J.-M. and Nam, J.-R. (2001), The Reality of Irregular Work and Policy Imperatives, (Seoul: KLI).

Ban, S. (1958), "Empirical Study on the Transfer of Land after Land Reform", 
Studies on Agricultural Economics, Korea Agricultural Economics Association.

Bang, K. (2001), "Ideological Roots of South Korean Land Reform”, in Hong (ed.).

Bank of Korea. Input-Output Tables. www.bok.or.kr.

Bank of Korea. National Accounts. www.bok.or.kr.

Chang, H. (2002), "Reconsideration of East Asian Industrial policy", in Lee and Chun (eds.).

Chang, H. and Jung, S. (2005), Solving the Entangled Korean Economy, (Seoul: Bookie).

Cho, Y. (2003), A Single Spark: The Biography of Chun Tae-il, (Seoul: Korea Democracy Foundation).

Chon, S. (2001), "Economic Policy and Land Distribution under U.S. Military Occupation", in Hong (ed.).

Chun, B. (2002), "The Flexibilisation of Labour Market after Economic Crisis", Monthly Labour Trends 4.

Chun, S. (2004), Not-Ended Song by Helpers, (Seoul: Hangyeore Newspaper Ltd).

Economic Planning Board. (1986), White Paper on Foreign Debts, (Seoul: EPB).

Fair Trade Commission. (2001), The 20-years History of Fair Trade Commission, (Seoul: FTC).

Gong, J. (1993), A Study on the Capitalist Class in the 1950s, (Seoul: Baeksanseodang).

Heo, S. (1999), "Critique on the Theory of Development and Expropriation”, Critical Review of History, Autumn.

Hong, S. (2001), "Land Reform and the Transformation of Korean Landlords", in Hong (ed.).

Hong, S. (ed.) (2001), Studies on Korea Land Reform, (Seoul: Yonsei University Press).

Hong, Y. (2003), "Park Jung Hee in the Era of Democracy", in Lee (ed.).

ISS of GSNU. (ed.) (2000), Korean War and Korean Capitalism, (Seoul: Hanul).

Jang, H. (1999), "Formation of Korean Development Strategies and Industrial Policies in 1960s", in Academy of Korean Studies (ed. 1999a).

Jang, S. (1984), “An Empirical Study on the process of Land Reform (1)", Studies on Economic History 8.

Jang, S. (1985), “An Empirical Study on the process of Land Reform (2)", Studies on Economic History 9.

Jang, S. (2000), "Land Reform and capitalist development in Korea - focused on the case of Gyeongnam Province", Studies on Development Economics 6: 1.

Jeong G. (2004), "The Present Situation and Movement of Migrant Workers in Korea", in Korean House for International Solidarity (ed.).

Jeong, B. (2003). "Reappraisal of Korea Land Reform - Date of its Completion, Driving Force and Character", Critical Review of History, Winter.

Jeong, J. (1995), "Dissolution of Pre-modern Residual of Social Status System after Liberation”, Journal of Institute for Social Science 13: 1, Gyeongsang National University. 
Jeong, J. (2000), “Korean War and Dissolution of Pre-modern Class Relations”, in ISS of GSNU (ed.).

Jeong, S. (1990), "Analysis of Marxian Ratios in the Korean Economy," Ph.D. Dissertation, Seoul National University.

Joo, M. (2005), "Competition and Monopoly in Korean Capitalism: 1987-2002”, Review of Social and Economic Studies 25.

Jun, G. (1996), “A Reappraisal of Korea's Land Reform Using Henry George's Paradigm", in Oh (ed.).

Kang, M. (ed.) (2000), History of Korean Capitalism, (Seoul: History Critique).

KCTU. (1997), Year Book of 1997, (Seoul: KCTU).

KCTU. (ed.) (2002), A Collection of the Analyses of Cases of the Struggle of Irregular Workers, (Seoul: KCTU).

Kim, H. (2002), “An Analysis of Cases of Enterprise-Level Unionisation”, in KCTU (ed.).

Kim, H.-K. (1988), Monopoly Capital and Wage Labor in Korea, (Seoul: Kachi).

Kim, J. (2000), "A Study on the Structural Changes in the Production and Distribution of Value in the Korean Economy", Ph.D. Dissertation, Hanyang University.

Kim, J.(ed.) (2001), Formation and Dissolution of the Korean Capitalist Development Model, (Seoul: Nanumuijip).

Kim, K. (2003), Was Chaebol Reform Finished, (Seoul: Hanul).

Kim, S., Chun, K., Jang, S. and Park, S. (1989), A Study on the History of Farmland Reform, (Seoul: KREI).

Kim, S.-K. (2005), "Marxian Theory and the Trend of Capital Accumulation in Korea”, Conference Paper, Korean Social and Economic Association.

Kim, S.-S. (1999), "Labour Policy and Capital-Labour Relations of 1960s in Korea", in Academy of Korean Studies (ed. 1999a).

Kim, S.-S. (2003), "Labour Policy and Capital-Labour Relations during the Park Jung Hee Era", in Lee (ed.).

Kim, T. (2005). "Land Reform by North Korean Government on the Occupied Territory in South Korea during Korean War," Critical Review of History, Spring.

Kim, Y. (2004), "The Size and Condition of Irregular Workers", Labour Society Bulletin 82.

Kim, Y. (2005), “The Extent and Realities of Irregular Workforce in 2005”, Labour Society Bulletin 105.

Korea International Trade Association, Korea Trade Statistics, http://global.kita. net/.

Korean Federation of Transportation, Public and Social Service Union (KFTPSU). (2002), A Report on Irregular Workers in KFTPSU Affiliated Firms, (Seoul: KFTPSU).

Korean House for International Solidarity (ed.) (2004), Report of Workshop for the Human Right of Workers in Korean Corporations Abroad and Meeting with Returned Migrant Workers, (Seoul: KHIS).

Korean Institute for Labor Studies \& Policy (KILSP) ed. (2000), Structural Adjustment 
and Counter-Strategy to Workplace Control, (Seoul: Nodongjeonseon).

Kwon, H. (2001), "An Evaluation of the Employment Policy of the Kim Dae-jung Government", in Kwon et al. (eds.).

Kwon, H. et al. (eds.) (2001), An Evaluation of Labour Policy of the Kim Dae-jung Government, (Seoul: FKTU).

Lee, B.-C. (1999), "Park Jung Hee Regime and Formation of Developmental State Model: Policy Change in the Mid-1960s", Studies in Economic Development 5: 2.

Lee, B.-C. (2003), "Political Economy of Developmental Dictatorship and Korean Experiences", in Lee (ed.).

Lee, B.-C. (ed.) (2003), Developmental Dictatorship and the Park Jung Hee Era, (Seoul: Changbee).

Lee, B.-H. and Hwang, D. (2000), "The Change in the Labour Market Structure after the Economic Crisis", in Yoon and Yoo (eds.).

Lee, I. and Chun, B. (eds.) (2002), East Asia in the Openness: Industry and Policy, (Seoul: Hanul).

Lee, J. (1994), "Postwar Land Reform and Capital Conversion Problem of the Landlord Class", Master's thesis, Yonsei University.

Lee, J. (2003), "Formation of Yushin System and North-South Korean Division”, in Lee (ed.).

Lee, Wan-Beom. (1999), "Formulation of the First 5-Years Economic Development Plan and U.S. Role in It", in Academy of Korean Studies (ed. 1999a).

Lee, Won-Bo. (2004), History of Korean Labour Movement 5: Labour Movement in Economic Development Period 1961-1987, (Seoul: Jisikmadang).

Ministry of Agriculture and Forestry. (1949), Reference Materials for Land Reform, (Seoul: MAF).

Ministry of Agriculture and Forestry. (1951), Summary of Farm Household Survey, (Seoul: MAF).

Ministry of Agriculture and Forestry. (1964), Agricultural Census: 1960, (Seoul: MAF).

Ministry of Agriculture and Forestry. (1974), History of Land Reform, (Seoul: MAF).

Ministry of Labor, The Survey Report on Wage Structure, various years, (with Raw Data).

National Statistical Office, Annual Report on the Economically Active Population Survey, various years. www.nso.go.kr.

National Statistical Office, The Report on Mining and Manufacturing Survey, various years, (Seoul: NSO).

Oh, D. (ed.) (1996), Patterns of Industrialization (2), (Seoul: Seoul National University Press).

Pang, K. (2001), "Ideological Roots of the South Korean Land Reform”, in Hong (ed.).

Park, H. (1994), "A Study on the Movement of the Rate of Profit and Economic Growth in the Korean Economy”, Ph.D. Dissertation, Chonnam National 
University.

Park, H. (1978), Theory of National Economy, (Seoul: Hangilsa).

Park, J. (1999), "Social Environment and Social Welfare Policy in 1960s", in Academy of Korean Studies (ed. 1999b).

Park, S. (2004), A Critical Reformulation of Left Theories of Modern Capitalism, (Seoul: Hanul).

Park, Y. (2002), “An Analysis of Cases of Ultra-Firm Level Unionisation”, in KCTU (ed.).

Pyo, H. (2003), "Estimates of Capital Stocks by Industries and Types of Assets in Korea (1953-2000)", Journal of Korean Economics Analysis 9: 1 (with unpublished update data).

Rieu, D. (2002), "A Study on the Formation Process of the National Economy Discourse", Economy and Society 56.

Seong, N. (1996), "A Study on Effects of the State Finance on the Economic Growth and Redistribution", Ph.D. Dissertation, Korea University.

Shin, G. (2001), "Social Origins of Land Reform in South Korea", in Hong (ed.).

Shin, Y. (2000), "A Critical Review of Economic Growth under the Park Regime", in Kang (ed.).

Sohn, H. (1991), New Conception on Korean Politics, (Seoul: Pulbit).

Woo, D. (2001), "Economic Consequences of Land Reform", in Hong (ed.).

Yang, W. and Hong, J. (1991), Analysis of Korean Capitalism, (Seoul: Ilbit).

Yoo, C. (2003), "Political and Institutional Conditions for Financial Repression", in Lee (ed.).

Yoo, C. (ed.) (2003), History and Crisis of the Korean Model for Capitalist Development, (Seoul: Hamkeiknunchaek).

Yoo, C. (ed.) (2006), Searching for a Korean Economic Model of Innovation and Integration, (Seoul: Hamkeiknunchaek).

Yoon, J. and Yoo, C. (eds.) (2000), Political Economy of Structural Adjustment, (Seoul: Pulbit).

\section{Works in Japanese}

Fine, B. (2003), "Beyond the Developmental State: Towards a Political Economy of Development", in Hirakawa et al. (eds.).

Hirakawa, H., Noguchi, M. and Sano, M. (eds.) (2003), Beyond Market-Driven Development: A New Stream of Political Economy of Development, (Tokyo: Nihon Hyoron Sha).

Nakatani, T. (1994), The Economics of Value, Price and Profit, (Tokyo: Keiso Sobo). 